\title{
ASSESSMENT OF MICROVASCULAR REACTIVITY AND OXIDATIVE STRESS IN HYPERTENSIVE ADOLESCENTS \\ AND HEMODIALYSIS PATIENTS
}

\section{PÉTER MONOSTORI Pharm.D.}

Supervisor: Prof. Dr. Sándor Túri, M.D., Ph.D., D.Sc.

Department of Pediatrics, Albert Szent-Györgyi Clinical Center University of Szeged, Szeged, Hungary

Ph.D. Thesis

Szeged

2010 


\section{ARTICLES RELATED TO THE THESIS}

I. Monostori P, Baráth A, Fazekas I, Hódi E, Máté A, Farkas I, Hracskó Z, Varga IS, Sümegi V, Gellén B, Bereczki C, Túri S. Microvascular reactivity in lean, overweight, and obese hypertensive adolescents. Eur J Pediatr. 2010; 169: 13691374. IF=1.634 (2009)

II. Monostori P, Hracskó Z, Karg E, Varga IS, Kiss Z, Boros T, Kiss É, Haszon I, Papp F, Sümegi V, Bereczki C, Túri S. Erythropoiesis-stimulating agent withdrawal and oxidative stress in hemodialysis. Clin Nephrol. 2009; 71: 521-526. IF=1.373 


\section{LIST OF ABBREVIATIONS}

\begin{tabular}{|c|c|}
\hline ACE & Angiotensin-converting enzyme \\
\hline $\mathrm{ACH}$ & Acetylcholine \\
\hline AIx & Augmentation index \\
\hline Ang II & Angiotensin II \\
\hline ANOVA & Analysis of variance \\
\hline BMI & Body mass index \\
\hline BP & Blood pressure \\
\hline CAT & Catalase \\
\hline CKD & Chronic kidney disease \\
\hline E-CAT & Erythrocyte catalase \\
\hline E-MDA & Erythrocyte malondialdehyde \\
\hline EPO & Erythropoietin \\
\hline ESA & Erythropoiesis-stimulating agent \\
\hline E-SOD & Erythrocyte superoxide dismutase \\
\hline ESRD & End-stage renal disease \\
\hline ET-1 & Endothelin-1 \\
\hline FMD & Flow-mediated dilation \\
\hline FOXO & Forkhead box class $\mathrm{O}$ \\
\hline GPx & Glutathione peroxidase \\
\hline GSH & Reduced glutathione \\
\hline GSSG & Oxidized glutathione \\
\hline GSSG/GSH & Ratio oxidized/reduced glutathione \\
\hline $\mathrm{Hb}$ & Hemoglobin \\
\hline HD & Hemodialysis; hemodialyzed \\
\hline HDL & High-density lipoprotein \\
\hline HPLC & High-performance liquid chromatography \\
\hline JNK & cJun- $N$-terminal kinase \\
\hline LDF & Laser Doppler flowmetry \\
\hline LDI & Laser Doppler imaging \\
\hline LDL & Low-density lipoprotein \\
\hline MDA & Malondialdehyde \\
\hline NO & Nitric oxide \\
\hline $\mathrm{NO}_{\mathrm{x}}$ & Plasma nitric oxide end-products \\
\hline PON1 & Paraoxonase-1 \\
\hline PORH & Postocclusive reactive hyperemia \\
\hline PWV & Pulse wave velocity \\
\hline $\mathrm{RBC}$ & Red blood cell \\
\hline RNS & Reactive nitrogen species \\
\hline ROS & Reactive oxygen species \\
\hline SNP & Sodium nitroprusside \\
\hline SOD & Superoxide dismutase \\
\hline
\end{tabular}




\section{TABLE OF CONTENTS}

1. Introduction ...........................................................................................................................1

1.1. Reactive species and antioxidants: physiology and pathophysiology .......................1

1.2. Oxidative stress in pathological states .....................................................................3

1.2.1. Primary hypertension and obesity in childhood: two interrelated diseases.............. 3

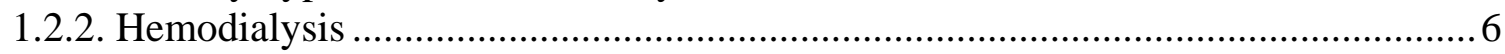

1.3. Assessment of the vascular system in pathological states .............................................7

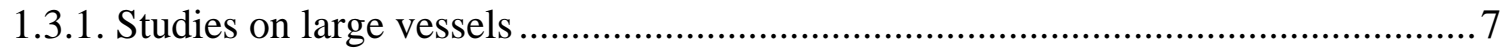

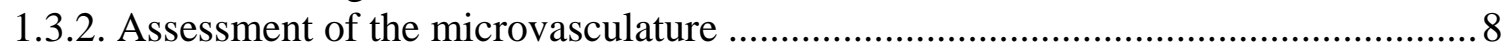

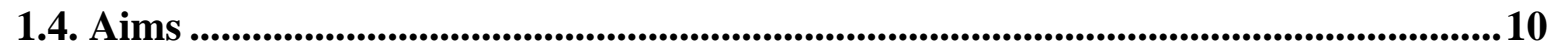

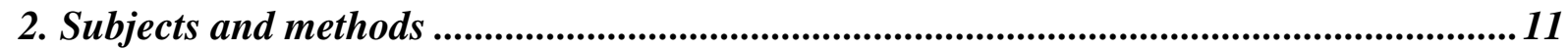

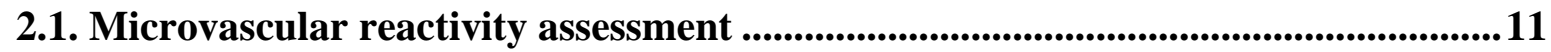

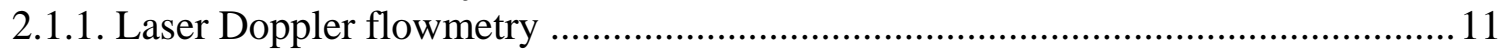

2.1.2. Validation of the laser Doppler flowmetry protocol .......................................... 11

2.2. Laboratory determinations............................................................................................. 13

2.2.1. Whole blood oxidized and reduced glutathione ................................................ 14

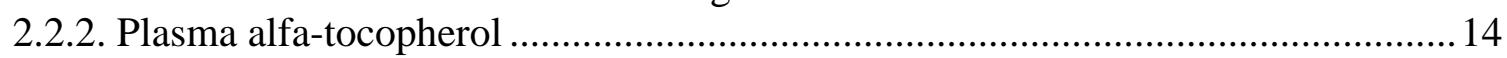

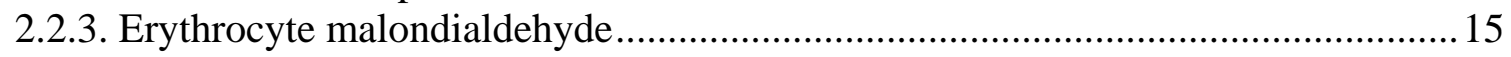

2.2.4. Erythrocyte superoxide dismutase and catalase activities .................................... 15

2.2.5. Determination of metabolic and hematological parameters ................................. 15

2.3. Study groups and interventions ........................................................................15

2.3.1. Microvascular reactivity in lean, overweight and obese hypertensive adolescents

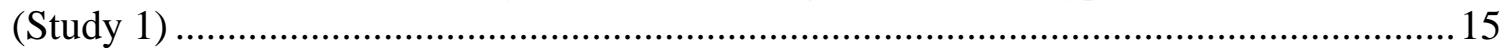

2.3.2. Erythropoiesis-stimulating agent withdrawal and oxidative stress in hemodialysis

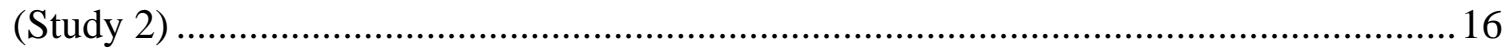

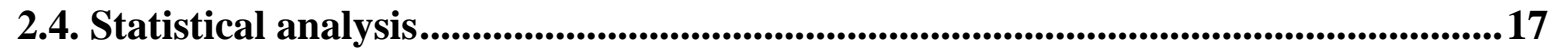

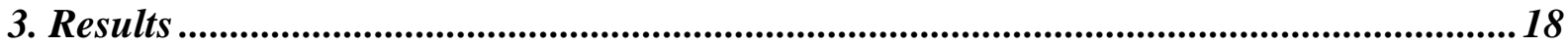

3.1. Microvascular reactivity in lean, overweight and obese hypertensive adolescents

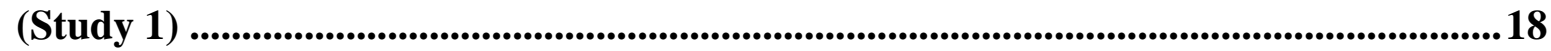

3.1.1. Epidemiological and clinical data on the study groups ...................................... 18

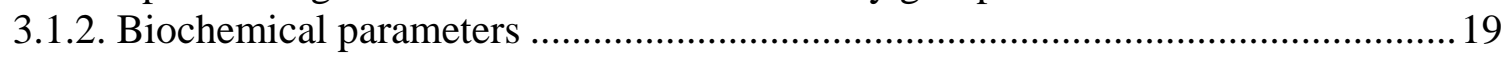

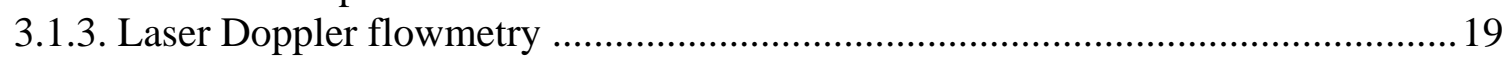

3.2. Erythropoiesis-stimulating agent withdrawal and oxidative stress in hemodialysis

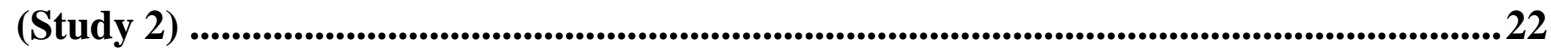

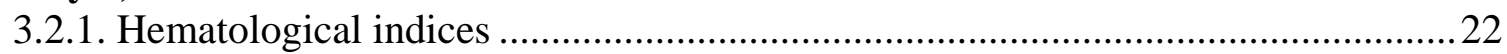

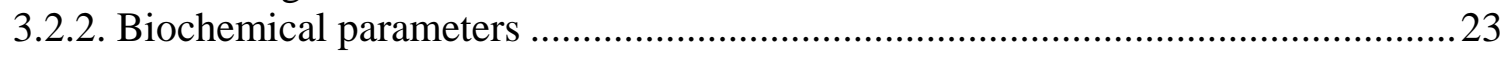

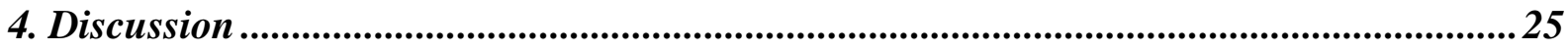


4.1. Microvascular reactivity in lean, overweight and obese hypertensive adolescents (Study 1)

4.2. Erythropoiesis-stimulating agent withdrawal and oxidative stress in hemodialysis (Study 2) .........................................................................................................................................27

4.3. Possible mechanisms and clinical significance of the findings ...............................27

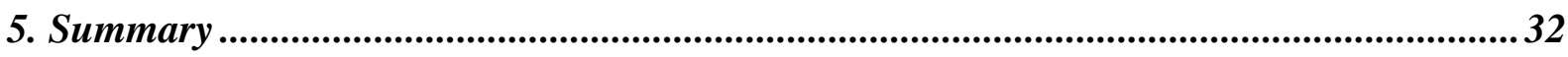

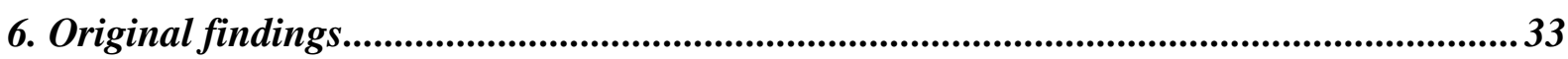

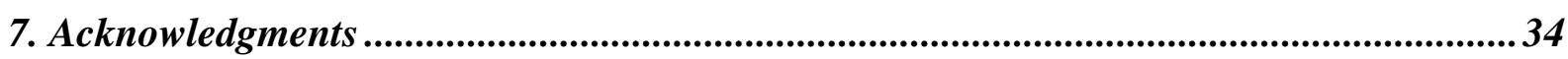

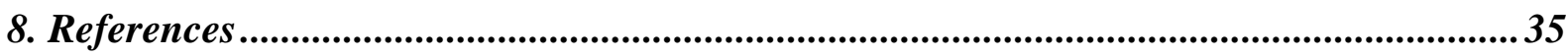

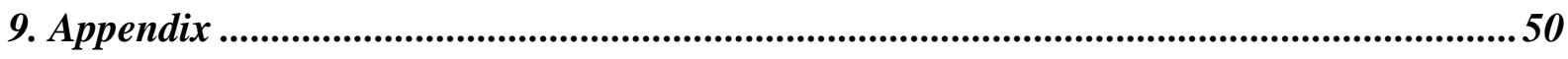




\section{INTRODUCTION}

\subsection{Reactive species and antioxidants: physiology and pathophysiology}

Reactive oxygen species (ROS) and reactive nitrogen species (RNS) are products of the normal cellular metabolism and play important roles in various physiological processes $[1,2]$. These include the defense against microorganisms (the oxidative burst in phagocytes); the redox regulation of the cell cycle; and the modulation of vascular tone, blood pressure (BP) and platelet aggregation, mediated by nitric oxide (NO) $[1,2]$.

Defense mechanisms against elevated concentrations of ROS and RNS involve enzymatic antioxidants such as superoxide dismutase (SOD), catalase (CAT), glutathione peroxidase (GPx) and the peroxiredoxin-thioredoxin-thioredoxin reductase system [1-3]; and nonenzymatic scavenging antioxidants, represented by reduced glutathione (GSH), ascorbic acid (vitamin C), alfa-tocopherol (vitamin E), carotenoids, flavonoids, urate and other antioxidants (Figure 1). Under normal conditions, the cell maintains a balance between the prooxidants and antioxidants, a state referred to as "redox balance" or "redox homeostasis". This equilibrium is essential for the survival of organisms and their health $[1,2]$. Thus, antioxidants not only serve as defense mechanisms against an overproduction of reactive species, but their proper functioning also allows ROS and RNS to fulfil their physiological roles [1-3].

Oxidative stress is defined as a disturbance in the prooxidant-antioxidant balance in favor of the former, leading to potential damage to important biomolecules (nucleic acids, lipids and proteins), often mediated by transition metals (iron, copper) [1-4]. ROS can react with all components of the DNA molecule, both the purine and pyrimidine bases and the deoxyribose chain. Permanent modification of the genetic material by ROS is the first step involved in mutagenesis, carcinogenesis and ageing [1]. ROS also attack polyunsaturated fatty acid residues of phospholipids, resulting in a decreased membrane fluidity, increased leakiness of the membrane, and inactivation of receptors and ion channels, as well as the formation of lipid peroxides and their by-products malondialdehyde (MDA), 4-hydroxy-2-nonenal (both mutagenic and toxic) and $\mathrm{F}_{2}$-isoprostanes (Figure 1) [1-3]. Additionally, ROS and RNS may 
induce damage to proteins, either reversible (such as the formation of mixed disulfides between protein thiol groups and low-molecular-weight thiols, in particular GSH ( $S$-glutathionylation)) or irreversible (carbonylation, nitrosylation and hydroxylation, resulting in generation of carbonylated proteins, nitrotyrosine, 3,4-dihydroxy-phenylalanine, ortho-tyrosine and meta-tyrosine) $[1,5,6]$. Such modifications can be detected in cardiovascular (e.g. hypertension, obesity and atherosclerosis), renal (chronic kidney disease (CKD) and end-stage renal disease (ESRD)) and pulmonary diseases (for example asthma and cystic fibrosis), and also in cancer and diabetes [1-7]. These modified molecules can serve as representative biomarkers of the oxidative/nitrosative damage involved in the pathophysiology of the diseases [4].

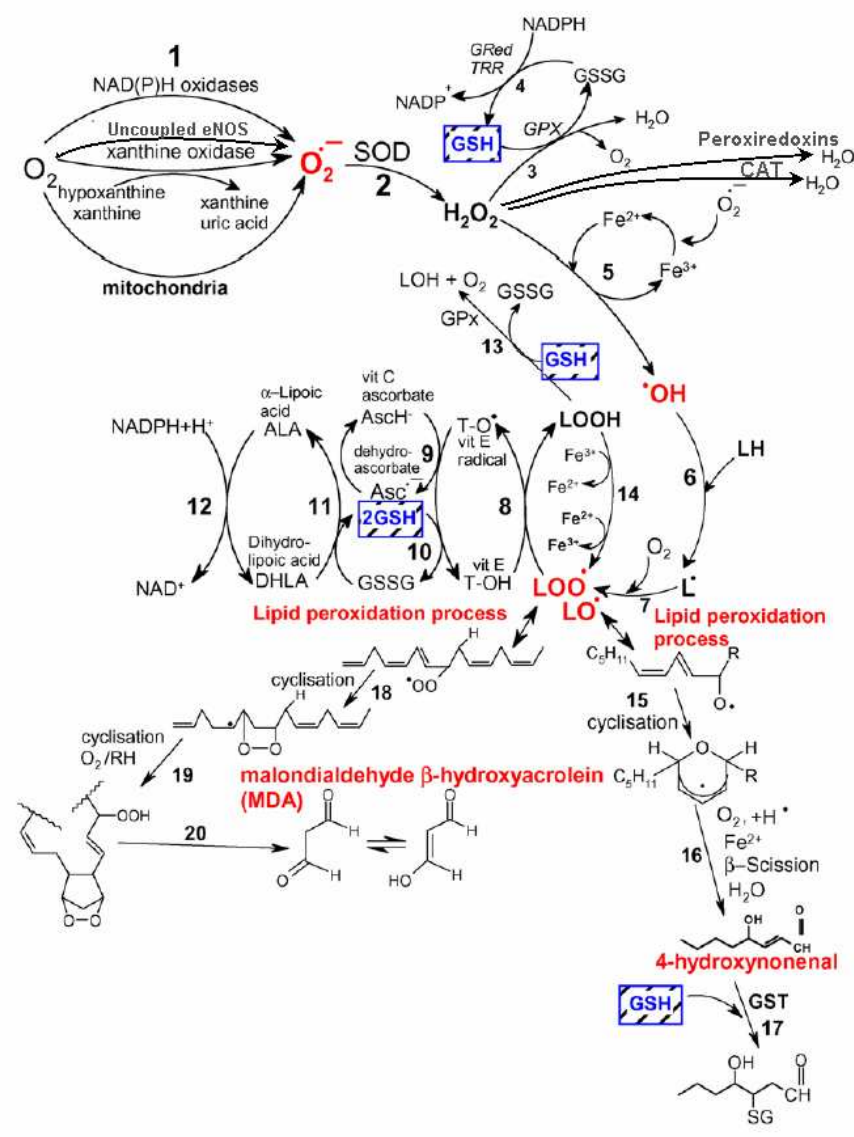

Figure 1: Pathways of ROS formation, the lipid peroxidation process and the role of enzymatic and nonenzymatic antioxidants in the management of oxidative stress. From Valko M. et al. Int J Biochem Cell Biol. 2007; 39: 44-84. [1] 


\subsection{Oxidative stress in pathological states}

\subsubsection{Primary hypertension and obesity in childhood: two interrelated diseases}

The definition of juvenile hypertension is based on the normative distribution of BP in healthy children, as a systolic and/or diastolic $\mathrm{BP} \geq 95^{\text {th }}$ percentile for age, gender and height (on at least three separate occasions) by The Fourth Report on the Diagnosis, Evaluation, and Treatment of High Blood Pressure in Children and Adolescents [8]. Even if hypertension in childhood is often of secondary origin [9-11] (in contrast with that in adulthood [12-14]), the prevalence of juvenile primary hypertension increases markedly with age, in particular from puberty $[9,10]$.

Primary (earlier term: essential) hypertension is a multifactorial and polygenic disorder in which the individual's genetic background, and various demographic and environmental factors play roles in the development of elevated BP [10, 12-15]. Factors that may contribute to the development and aggravation of hypertension include obesity, insulin resistance, renal microvascular alterations, oxidative stress and an endothelial dysfunction [13]. The major pathways leading to an elevation of BP via ROS formation are depicted in Figure 2 [16]. The inducing effects of various agents, such as salt, vasopressin, endothelin-1 (ET-1), renin, angiotensin II (Ang II) and aldosterone, lead to an increased abundance of ROS, which, in turn, can induce vasoconstriction, vascular and myocardial hypertrophy, a decreased kidney function, and increased sympathetic efferent activity from the central nervous system, contributing to the development of hypertension [16]. The closed reaction loops, leading to the uncoupling of nitric oxide synthase, the activation of xanthine oxidase, and the generation of ET-1 and Ang II, are possible mechanisms of persistence of the BP elevation (Figure 2) [16]. 


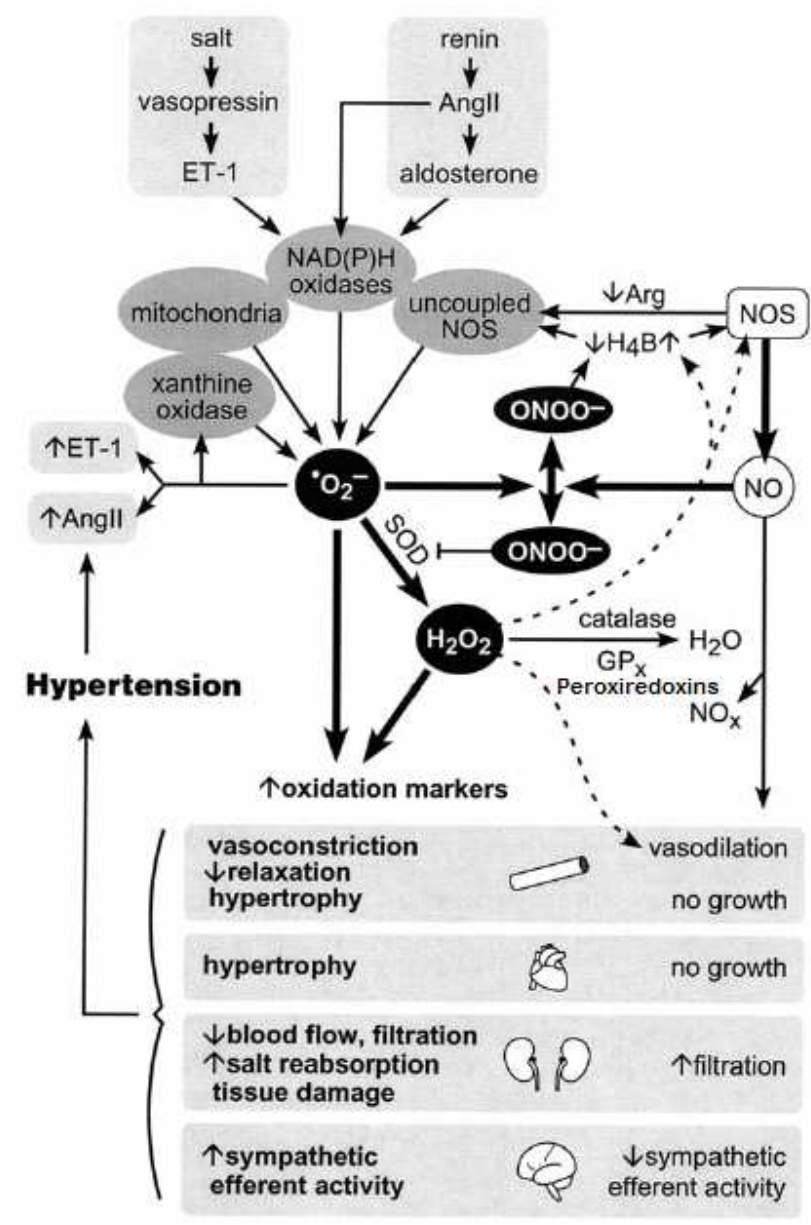

Figure 2: Major pathways leading to hypertension via reactive oxygen species formation. From Lassegue B, Griendling KK. Reactive oxygen species in hypertension. Am J Hypertens. 2004; 17: 852-860. [16]

An increasing number of children and adolescents exhibit excess weight, which comprises a major issue in public health due to the increased risk of development of chronic diseases [17]. The prevalence of overweight in adolescents varies from under $5 \%$ to more than $20 \%$, being higher in the Western and Southern regions of Europe and in the United States $[18,19]$. However, the exact number depends on geographical and ethnical factors, and the definition of obesity itself [18-20].

The body mass index (BMI) is the parameter most widely used to assess childhood overweight, even if it is only an indirect measure of adiposity and has limitations as compared with other techniques $[17,20]$. Due to the fact that the BMI in children varies greatly with age and sex [20], percentiles (such as those specified by the Centers for Disease Control and 
Prevention in 2000 [21]), or the age and sex-specific cut-off points set by the International Obesity Task Force [22] are used to define childhood overweight and obesity.

Obesity per se exerts unfavorable effects on several organs such as the lung, liver, kidney and heart [17], and is associated with a proinflammatory state [23] and activation of vascular endothelial cells and platelets [24], as well as higher prevalences of insulin resistance [25], type 2 diabetes [26] and dyslipidemia [27]. The above alterations and the increased cardiovascular risk of overweight subjects have been shown in obesity intervention programs to be partly reversible [28-31]. It is noteworthy that the level of oxidative stress is increased and the antioxidant defense is compromised in obesity [32], as shown by the increased formation of superoxide [33] and peroxyl radicals [34], higher levels of MDA [35] and $\mathrm{F}_{2}$-isoprostanes [24], reduced concentrations of alfa-tocopherol and beta-carotene [36], and lower activities of SOD and GPx [37].

Excess weight is one of the most important factors predisposing to hypertension [38]. The interrelation between overweight and hypertension is complex, involving (among others) activation of the sympathetic and renin-angiotensin-aldosterone systems, and various metabolic and vascular changes (e.g. insulin resistance, decreased NO availability and renal sodium excretion, and increased levels of plasma lipids and ET-1), often manifested as the metabolic syndrome [38-40]. These effects have been suggested to be mediated, in part, by hyperleptinemia and leptin resistance in obesity [40].

In view of the facts that adult hypertension [41, 42] and obesity [37] are associated with an increased level of oxidative stress, we previously hypothesized that oxidative stress may be an important feature in juvenile hypertension too. In line with this, increased levels of oxidized glutathione (GSSG), elevated ratios of oxidized/reduced glutathione (GSSG/GSH), decreased GSH levels, impaired GSH regeneration and a more pronounced lipid peroxidation have been demonstrated in adolescent hypertensives [43]. However, no differences were observed in the paraoxonase-1 (PON1) activities, PON1 Q192R genotype or homocysteine levels in this patient group, irrespective of the degree of obesity [44]. Next, we set out to examine whether a short-term antihypertensive treatment could reveal differences in markers of oxidative stress and endothelial dysfunction between lean or obese hypertensive adolescents [45]. Before medication, elevated activities of the angiotensin-converting enzyme (ACE) were found in the lean hypertensives as compared with the controls. In contrast, the obese hypertensive group 
demonstrated a higher heart rate and elevated levels of xanthine oxidase activity, ET-1 and leptin at baseline. In both groups, the levels of the plasma $\mathrm{NO}$ end-products $\left(\mathrm{NO}_{\mathrm{x}}\right)$ and free thiols were decreased, and the ratios $\mathrm{MDA} / \mathrm{NO}_{\mathrm{x}}$ were increased before treatment. $\mathrm{ACE}$ inhibitor therapy normalized the levels of $\mathrm{NO}_{\mathrm{x}}$ and the ratios $\mathrm{MDA} / \mathrm{NO}_{\mathrm{x}}$ only in the obese hypertensives. These results suggested that the pathomechanisms of juvenile hypertension associated with normal body weight or obesity may differ [45].

\subsubsection{Hemodialysis}

The incidences of CKD and ESRD show increasing trends, in part due to the ever more frequent prevalence of their underlying diseases, in particular diabetes [46]. Other causes include hypertension, glomerulonephritis, chronic pyelonephritis and cystic kidney disease [46]. The risk of cardiovascular events in ESRD patients is 3.5-50 times higher than that in the general population [7]. Besides classical cardiovascular risk factors (e.g. diabetes, hypertension and dyslipidemia), uremia-associated factors such as a chronic volume expansion, inflammation, oxidative stress and anemia also play roles [7, 47].

Uremia itself is regarded as a prooxidant state, and the oxidative stress becomes more severe together with the severity of CKD [7, 48]. Despite beneficial effects due to the removal of uremic toxins and excess fluid [49], hemodialysis (HD) sessions may themselves induce repetitive bouts of oxidative stress [7, 50,51], as indicated by increased levels of MDA and organic hydroperoxides, decreased activities of SOD and GPx, and lower concentrations of selenium, zinc and copper [52]. The dialysis modalities, including the dialysis dose and frequency $[49,53]$, the type of dialysis membrane used [54-56], and the presence of glucose in the dialyzing fluid [57], may also affect oxidative stress.

Anemia is a common feature of CKD and ESRD, and is associated with elevated levels of morbidity and mortality in HD patients [58]. The current Revised European Best Practice Guidelines for the Management of Anemia in Patients with Chronic Renal Failure [59] state that the fundamental treatment choices in anemia correction are the administration of erythropoiesis-stimulating agents (ESAs), iron and adjuvant vitamins (for example, vitamin E, vitamin $\mathrm{C}$ and folate), and in HD patients, optimization of the dialysis process [59]. 
Despite a transient increase in the levels of oxidative markers after the initiation of ESA therapy [60] (preventable with simultaneous vitamin E administration [61]), long-term ESA treatment is thought to have antioxidant effects [62-66], though the mechanisms have not been well established [67]. These mechanisms are suggested to include elevated expressions of the enzymes SOD, CAT, GPx [62-65] and heme oxygenase-1 [66], and attenuated lipid peroxidation $[64,65]$. Factors associated with the reduction of iron-dependent oxidative injury [68] and the correction of anemia [65,69] may also play roles in the improvement of oxidative stress. Before our studies, however, it was not known whether a short-term withdrawal of ESA treatment has an influence on the indices of oxidative stress.

\subsection{Assessment of the vascular system in pathological states}

\subsubsection{Studies on large vessels}

Among the various techniques developed for the assessment of the macrovasculature, the measurement of arterial stiffness is being increasingly used in the clinical setting [70]. The pulse wave velocity (PWV) and the augmentation index (AIx) are reproducible parameters with which to characterize arterial stiffness and pulse wave reflection, respectively [70], as measured noninvasively by means of applanation tonometry, piezoelectricity or oscillometry (a recent technique developed by Illyés and colleagues) [71-73]. The carotid-femoral PWV (considered the gold-standard measurement of arterial stiffness [70]) is elevated in adult patients with obesity [74] and uncomplicated primary hypertension [75], and in those on HD [76]. The carotid-femoral PWV is of independent predictive value for all-cause mortality, cardiovascular morbidity, coronary events and stroke in hypertension [75] and HD [76]. In adult hypertensives with or without the metabolic syndrome, the peripheral (radial) PWV and AIx have likewise been reported to be increased [77]. As concerns juvenile primary hypertension, the brachial-ankle PWV has been reported to be greater in hypertensive adolescents, but the patients were not selected according to the degree of adiposity [78].

Another technique, forearm venous occlusion plethysmography, is based on the interruption of the venous outflow from the arm by the compression of a cuff at a pressure that leaves the arterial flow unaltered [79]. This causes the forearm blood volume to rise. The 
rate and degree of swelling reflects the forearm vascular resistance, which, in turn, is related to the vascular endothelial function $[79,80]$. Venous occlusion plethysmography is often used in combination with complete occlusion and subsequent release of the arm (postocclusive reactive hyperemia (PORH) test) or brachial artery catheterization [79, 80]. Even if the latter allows assessment of the responses to endothelium-dependent and -independent vasoactive agents, its applicability is limited due to its invasive nature [79]. As examples, the impaired endothelial function of the brachial artery was confirmed in both hypertensive adults [81] and HD patients [82] in earlier studies in which this technique was used.

The working principle of the third method, brachial artery flow-mediated dilation (FMD), is the change in the arterial diameter in response to increased shear stress [79]. Dilation of the artery after the PORH test or due to a sublingual dose of nitroglycerin (endotheliumindependent vasodilation) is monitored by means of vascular ultrasonography [79]. Even if brachial artery FMD has some limitations (e.g. substantial intra- and inter-observer variance), this technique is most commonly performed and best validated for the noninvasive assessment of the conduit vessel function [83]. FMD has been reported to be impaired in obese children $[23,84]$ and in patients on HD [85]. A relationship between the brachial artery FMD, the carotid artery intima-media thickness and the levels of vascular inflammatory markers was recently demonstrated in obese hypertensive children [86]. Importantly, a decreased brachial artery FMD in adult hypertension [77, 87] has been suggested to have a prognostic role in identifying patients at higher risk of nonfatal or fatal cardiovascular events [88].

\subsubsection{Assessment of the microvasculature}

The definition of "microcirculation" is based on the vessel physiology rather than diameter or structure [89]. Accordingly, all vessels that respond to increasing pressure by a myogenic reduction in lumen diameter are considered part of the microcirculation. Such a definition includes the smallest arteries and arterioles in the microvasculature in addition to capillaries and venules [89]. The functions of the microcirculation include the delivery of nutrients and the removal of waste products from all cells of the body; the avoidance of large fluctuations in hydrostatic pressure at the level of the capillaries that would otherwise impair capillary 
exchange; and a contribution to the overall peripheral resistance (due to a substantial drop in hydrostatic pressure at this level of the circulation) [89].

Laser Doppler flowmetry (LDF) and laser Doppler imaging (LDI) are noninvasive means of assessment of the microvascular function $[90,91]$. This technique is based on the scattering and frequency-shift of monochromatic laser light due to its interaction with moving blood cells (Figure 3A) [90, 91]. Laser Doppler methods measure the microvascular blood perfusion (termed the flux), which is the product of the velocity and concentration of the moving blood cells within the measured volume [90]. LDF and LDI provide an estimate of perfusion up to a depth of 1 to $1.5 \mathrm{~mm}$ into the dermis and thus mainly measure the perfusion in the arterioles, venules and capillaries [91]. LDI makes use of a laser beam that scans across a predetermined area, resulting in a two-dimensional map of the blood perfusion. LDI has a better spatial resolution and smaller site-to-site variability as compared with LDF [91]. LDF, in turn, allows continuous monitoring of the flux at a specified point of the skin, offers higher sensitivity and has the ability to detect rapid perfusion changes [90].

Due to the relatively large spatial and temporal variabilities of the technique, the response of the microvessels to provocation tests is assessed, instead of the basal flux. These tests include thermal challenges (local or systemic heating or cooling), iontophoretic administration of vasoactive drugs, the PORH test, or a combination of them (Figure 3B) [90,91]. For further details relating to the standardization of microvascular reactivity measurements with the LDF technique, see Section 2.1.1.
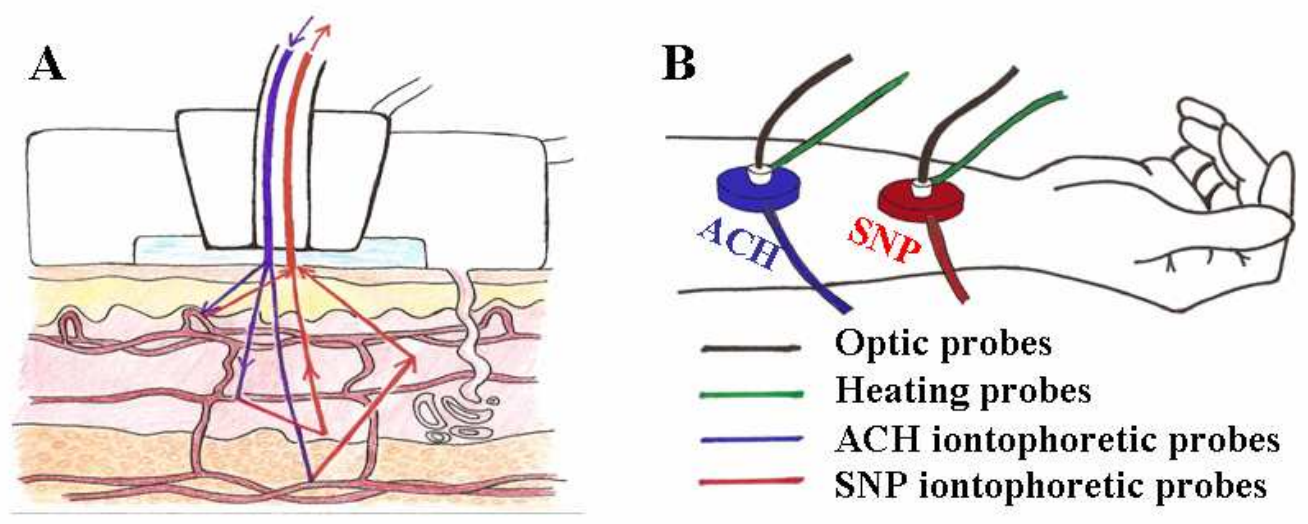

Figure 3: A: Theory of the laser Doppler flowmetry technique. B: Schematic plot for the probe settings during laser Doppler flowmetry measurement. ACH: acetylcholine; SNP: sodium nitroprusside. 
The skin microvascular reactivity, as measured by means of the laser Doppler technique, has been reported to correlate with other methods applied to assess the vascular function in distinct vascular beds, including brachial artery FMD [92,93] and transthoracic coronary echocardiography [94]. The functional impairment of the microvascular system in HD affects both the endothelium-dependent [95-97] and -independent vasodilations [96, 97]. In contrast, only the endothelium-dependent microvascular reactivity is affected in adult hypertension, as shown by attenuated LDF flux responses to occlusion of a limb and iontophoretic administration of vasodilators [98], or to local heating and iontophoresis [99], whereas the endothelium-independent function is preserved [98, 99].

Due to its simple, convenient and painless nature, LDF is highly appropriate for the examination of children and adolescents. Before our studies, however, no data were available regarding the functional properties of the microvasculature in juvenile primary hypertension.

\subsection{Aims}

We set out to answer the following questions:

1. Is there a detectable alteration in the microvascular reactivity in juvenile primary hypertension? Is the microvascular reactivity impaired or augmented? Is the endothelium-dependent or the -independent reactivity changed?

2. Is there any variance in the microvascular reactivity as a function of the BMI in adolescent hypertensives?

3. Does the level of oxidative stress correlate with the microvascular reactivity in juvenile hypertensives and HD patients?

4. Do the characteristics of the treatment with ESA (the type and the withdrawal of ESA) influence the oxidative stress in HD? 


\section{SUBJECTS AND METHODS}

\subsection{Microvascular reactivity assessment}

\subsubsection{Laser Doppler flowmetry}

Microvascular reactivity studies were performed in a temperature-controlled room $\left(24{ }^{\circ} \mathrm{C}\right)$ between 9 a.m. and noon, the subjects being in the fasted state. They were lying in a supine position with their feet at the heart level. After a 15-min equilibration, the volar surface of the right forearm (in HD patients, the forearm contralateral to the Cimino fistula) was gently cleaned with alcohol. The microvascular perfusion of the skin was continuously measured at two sites (distance of separation: 6-8 $\mathrm{cm}$ ) by means of a DRT4 laser Doppler flowmeter (laser wavelength: $780 \mathrm{~nm}$, Moor Instruments Ltd., Axminster, UK). The optic probes (DP12-V2) fit into the heater probes (SHP2), which, in turn, fit into the iontophoresis chambers (ION1, surface area: $0.71 \mathrm{~cm}^{2}$; all Moor Instruments Ltd., Axminster, UK). This setting allows perfusion measurements at skin sites affected by iontophoretic and local thermal provocations (Figure 3B). The positions of the probes were chosen so as to avoid hair and injured skin. A MIC2 Iontophoresis Device (Moor) was utilized for the parallel delivery of freshly prepared $1 \%$ isotonic saline solutions of the endothelium-dependent vasodilator acetylcholine (ACH) and the endothelium-independent vasodilator sodium nitroprusside (SNP) (both SigmaAldrich, St. Louis, MO, USA), using separate chambers (at sites 1 and 2, respectively). The local skin temperature was standardized at $33{ }^{\circ} \mathrm{C}$ during the iontophoresis sequence, and subsequently increased to $44{ }^{\circ} \mathrm{C}$ by means of a SH02 Skin Heating Unit (Moor).

\subsubsection{Validation of the laser Doppler flowmetry protocol}

The LDF protocol used in the present work was adapted with modifications from Khan et al. [100]. It consisted of a 4-min measurement of the baseline perfusion, followed by 3 consecutive, increasing iontophoretic doses of ACH and SNP (current: $20 \mu \mathrm{A}$, duration: 20, 40 and $80 \mathrm{~s}$, respectively; yielding a total charge of $2.8 \mathrm{mC}$ and a total charge density of 
$3.94 \mathrm{mC} / \mathrm{cm}^{2}$ ). Between iontophoretic doses, 4-min intervals with no current administration were allowed. Following an additional 10-min interval after completion of the iontophoresis sequence, both measurement sites were gradually heated at a rate of $0.1{ }^{\circ} \mathrm{C} / \mathrm{s}$ [101] to reach and maintain a temperature of $44{ }^{\circ} \mathrm{C}$ for $25 \mathrm{~min}$, corresponding to maximal vasodilation. A typical blood flow curve in response to the above LDF protocol is shown in Figure 4.

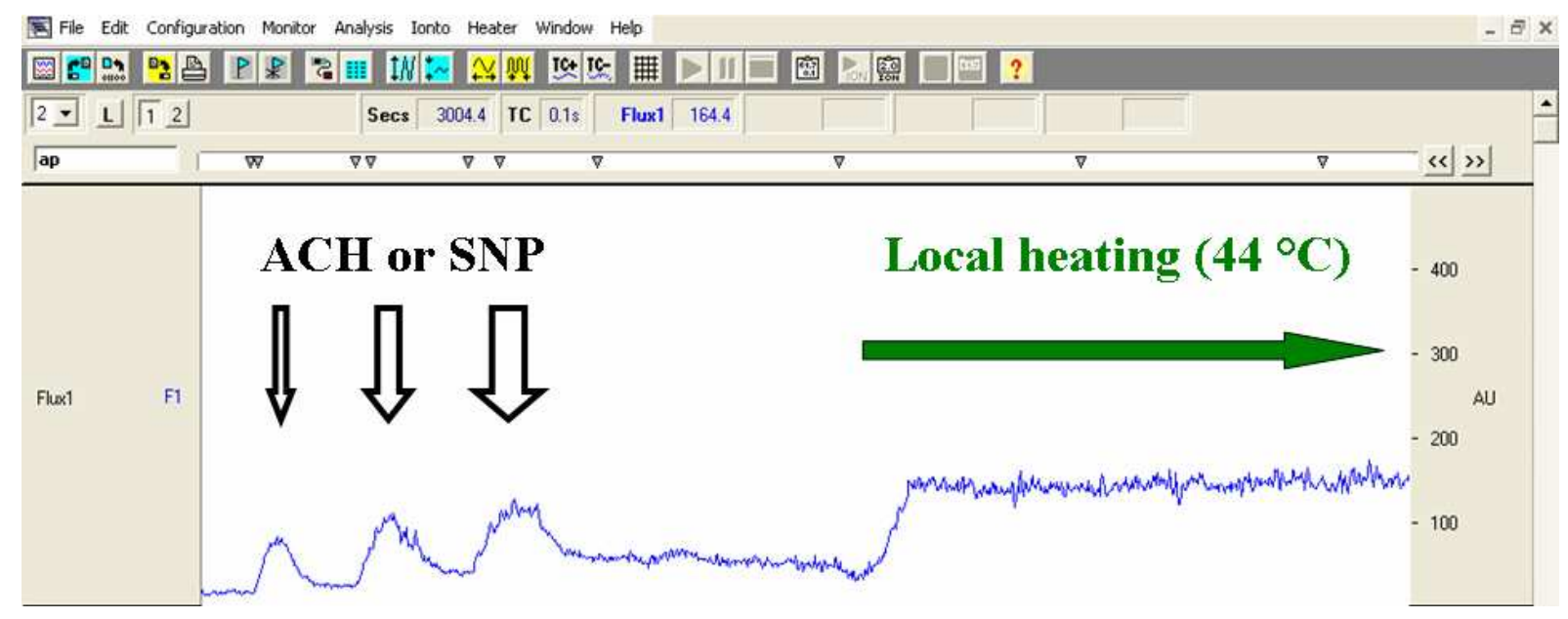

Figure 4: Typical blood flow curve. ACH: acetylcholine; SNP: sodium nitroprusside.

Flux values at baseline and in the plateau phase of the local heating response were evaluated by averaging 60-s intervals. Average values of 20 -s intervals were used as peak perfusion responses after each iontophoretic dose. All counted perfusion values were expressed relative to the baseline values (baseline $=100 \%$ ).

The original LDF protocol [100] was modified in order to meet recent recommendations with which to avoid measurement artifacts such as current-induced hyperemia [102-104]. A lower current was applied $(20 \mu \mathrm{A}$, instead of $100 \mu \mathrm{A})$ and isotonic saline was used instead of deionized water as the solvent for vasoactive drugs. In accord with this, we observed no changes in the flux when isotonic saline was iontophoresed by using the above protocol. The within-subject variabilities determined at fixed skin sites of healthy young subjects were $15-25 \%$ for both iontophoretic and local thermal provocations in our laboratory. 
In order to validate the modified LDF protocol in the clinical setting, the microvascular reactivities of $12 \mathrm{HD}$ patients were assessed as the presence of an impaired microvascular function had previously been demonstrated in this group [95-97]. In agreement with the literature, the endothelium-dependent and -independent vasodilation both proved to be markedly diminished as compared with those in healthy young subjects $(p<0.001 v s$ the controls; data not published) (Table 1). The study protocol was well tolerated by both the patients and the controls, and no adverse local events (pain or red flare) or systemic effects (change in BP, heart rate or respiratory rate) were observed.

\begin{tabular}{|c|c|c|}
\hline & $\begin{array}{c}\text { Controls } \\
(n=19)\end{array}$ & $\begin{array}{l}\text { HD patients } \\
\quad(n=12)\end{array}$ \\
\hline $1^{\text {st }} \mathrm{ACH}$ iontophoresis & $\begin{array}{c}367.0 \\
(100.0-499.0)\end{array}$ & $\begin{array}{c}110.0 \\
(100.0-473.0)\end{array}$ \\
\hline $2^{\text {nd }} \mathrm{ACH}$ iontophoresis & $\begin{array}{c}860.0 \\
(150.0-1854.0)\end{array}$ & $\begin{array}{c}176.0 \\
(100.0-752.0)^{* * * *}\end{array}$ \\
\hline $3^{\text {rd }}$ ACH iontophoresis & $\begin{array}{c}1339.0 \\
(577.0-2187.0)\end{array}$ & $\begin{array}{c}289.0 \\
(151.0-914.0)^{* * * *}\end{array}$ \\
\hline Local heating to $44^{\circ} \mathrm{C}$ (site 1$)$ & $\begin{array}{c}2087.0 \\
(909.0-3245.0)\end{array}$ & $\begin{array}{c}513.0 \\
(235.0-1263.0)^{* * *}\end{array}$ \\
\hline $1^{\text {st }} \mathrm{SNP}$ iontophoresis & $\begin{array}{c}367.0 \\
(100.0-499.0)\end{array}$ & $\begin{array}{c}110.0 \\
(100.0-467.0)\end{array}$ \\
\hline $2^{\text {nd }} \mathrm{SNP}$ iontophoresis & $\begin{array}{c}860.0 \\
(150.0-1854.0)\end{array}$ & $\begin{array}{c}333.0 \\
(100.0-669.0)^{* * * *}\end{array}$ \\
\hline $3^{\text {rd }}$ SNP iontophoresis & $\begin{array}{c}1339.0 \\
(577.0-2187.0)\end{array}$ & $\begin{array}{c}412.0 \\
(100.0-829.0)^{* * *}\end{array}$ \\
\hline Local heating to $44^{\circ} \mathrm{C}$ (site 2 ) & $\begin{array}{c}2087.0 \\
(909.0-3245.0)\end{array}$ & $\begin{array}{c}654.0 \\
(221.0-1373.0)^{* * *}\end{array}$ \\
\hline
\end{tabular}

Table 1: Skin blood flux values in response to three doses of acetylcholine (site 1) and sodium nitroprusside (site 2) iontophoresis and local heating to $44{ }^{\circ} \mathrm{C}$ (LDF protocol validation). Data are expressed relative to the baseline values (medians (ranges), baseline $=100 \%$ ). LDF: laser Doppler flowmetry; HD: hemodialyzed. Kruskal-Wallis test and Dunn's multiple comparison test. ${ }^{* * *} p<0.001$ vs controls.

\subsection{Laboratory determinations}

For determination of the biochemical, metabolic and hematological parameters, blood samples containing EDTA or heparin were used. In Study 1 (Microvascular reactivity in lean, 
overweight and obese hypertensive adolescents), venous blood was obtained prior to the LDF measurements. In Study 2 (Erythropoiesis-stimulating agent withdrawal and oxidative stress in hemodialysis), blood samples were taken from the arterial line of the dialysis tubes. For the biochemical determinations, we used samples drawn at the end of the long interdialytic period so as to minimize the acute effects of the dialysis session or intravenous iron administration on the indices of oxidative stress $[7,105]$. The possibly higher degree of fluid retention had no effect on the oxidative parameters, as either normalization to the hemoglobin $(\mathrm{Hb})$ levels was performed (GSSG and GSH) or erythrocyte concentrations and activities were determined (MDA and antioxidant enzymes, respectively). The hematological parameters were measured from mid-week blood samples according to current guidelines [59].

\subsubsection{Whole blood oxidized and reduced glutathione}

Whole blood levels of GSSG and GSH were assayed by means of a spectrophotometric enzymatic recycling method [105]. In the presence of 5,5'-dithio-bis(2-nitrobenzoic acid), glutathione reductase and nicotinamide adenine dinucleotide phosphate (reduced form), the colored product 5-thionitrobenzoate is formed upon the progressive reduction of GSSG to GSH. The rate of color change at $412 \mathrm{~nm}$, followed over $3 \mathrm{~min}$, is proportional to the total glutathione (i.e. GSSG plus GSH) concentration. GSSG was determined via the blocking of GSH with the thiol-masking agent $N$-ethylmaleimide in a separate sample.

\subsubsection{Plasma alfa-tocopherol}

Plasma alfa-tocopherol was determined by means of high-performance liquid chromatography (HPLC), using a 4.0x250 mm Spherisorb ODS2 $5 \mu \mathrm{m}$ reverse-phase HPLC column (Waters Corp., Milford, Massachusetts, USA) and a variable-wavelength ultravioletvisible detector (at $297 \mathrm{~nm}$ ) [107]. The levels of plasma alfa-tocopherol are reported relative to the total cholesterol plus triglyceride levels. 


\subsubsection{Erythrocyte malondialdehyde}

Erythrocyte MDA (E-MDA), after its reaction with thiobarbituric acid, was measured by means of HPLC, using a 3.9x300 mm $\mu$ Bondapak C18 $10 \mu \mathrm{m}$ reverse-phase HPLC column (Waters Corp., Milford, Massachusetts, USA) and a variable-wavelength ultraviolet-visible detector (at $532 \mathrm{~nm})$ [108].

\subsubsection{Erythrocyte superoxide dismutase and catalase activities}

The activity of the erythrocyte SOD (E-SOD) was measured according to Misra and Fridovich [109], modified by Matkovics et al. [110]. The assay is based on the inhibition of the epinephrine-adrenochrome transformation by SOD, detected at $480 \mathrm{~nm}$ by means of spectrophotometry.

The activity of the erythrocyte CAT (E-CAT) was determined with the method of Beers and Sizer [111], measuring the breakdown of hydrogen peroxide by CAT, detected at $240 \mathrm{~nm}$ with spectrophotometry.

The enzyme activities are given relative to the protein concentration of the sample, determined at $675 \mathrm{~nm}$ with the spectrophotometric method of Lowry et al. [112].

\subsubsection{Determination of metabolic and hematological parameters}

Plasma levels of the total, high- and low-density lipoprotein (HDL and LDL) cholesterol and triglycerides, as well as $\mathrm{Hb}$ levels, proportions of reticulocytes, transferrin saturation values and ferritin levels, were determined with standard laboratory methods.

\subsection{Study groups and interventions}

\subsubsection{Microvascular reactivity in lean, overweight and obese hypertensive adolescents (Study 1)}

Primary hypertensive patients (aged 6-19) with a confirmed diagnosis were asked to participate in Study 1. Hypertension was defined as a 24-h systolic and/or diastolic mean BP 
equal to or greater than the $95^{\text {th }}$ percentile for age, height and sex [113], measured with an oscillometric ambulatory BP monitor (Meditech ABPM-04, Budapest, Hungary). Secondary causes of hypertension (renal parenchymal, renovascular, endocrinological, cardiological or neurological) were excluded. No proteinuria (defined as $>10 \mathrm{mg} / \mathrm{kg} / \mathrm{day}$ ) or any impairment in renal function (creatinine clearance $<80 \mathrm{ml} / \mathrm{min} / 1.73 \mathrm{~m}^{2}$ ) was observed. Of the 33 adolescents enrolled after establishment of the diagnosis of primary hypertension in the Department of Pediatrics, University of Szeged, 10 patients had a normal BMI (lean hypertensive (LH) group), while 13 adolescents were classified as overweight hypertensive (OWH) and 10 patients as obese hypertensive (OBH) according to the age and sex-specific cut-off points of child overweight and obesity defined by the International Obesity Task Force [22]. Most patients were enrolled within 3 months after establishment of their diagnosis (in 1, 4 and 2 subjects in the LH, OWH and OBH groups, respectively: within 6-10 months). Five LH, 6 $\mathrm{OWH}$ and $1 \mathrm{OBH}$ patient had familiar predisposition to hypertension. Nineteen healthy adolescents with no evidence of cardiovascular or renal disorders served as controls, recruited from secondary schools in Szeged. For all groups, exclusion criteria included the presence of an acute illness, smoking, and taking medication (in the previous 5 days) or beverages (on the previous day) known to affect microvascular perfusion. Three $\mathrm{OWH}$ and $2 \mathrm{OBH}$ patients had been on short-term metoprolol therapy antecedent to the present study. No signs of acute inflammation or systemic infection were revealed by means of physical examination and qualitative blood count in any of the patients or controls. Written informed consent was obtained from the patients, the controls and their parents prior to the study, which was approved by the Ethical Committee of the University of Szeged.

\subsubsection{Erythropoiesis-stimulating agent withdrawal and oxidative stress in hemodialysis (Study 2)}

Twenty-one patients on chronic HD were enrolled in Study 2, dialyzed in two distinct morning shifts (11 patients: age (mean) \pm SD $59.3 \pm 17.7 \mathrm{yrs}$, time on HD: $3.6 \pm 2.0 \mathrm{yrs}$; and 10 patients: age $56.6 \pm 13.6 \mathrm{yrs}$, time on HD: $4.3 \pm 2.1 \mathrm{yrs}$, respectively). All patients were on 4-h bicarbonate HD, performed on a Polyflux 21L dialyzer, 3 times a week. The single-pool Kt/V was greater than 1.4, in line with the current European Best Practice Guideline on Dialysis 
Strategies [114]. Heparin was used as the anticoagulant during HD. The primary diagnoses were chronic glomerulonephritis, chronic pyelonephritis or hypoplastic kidney. No patients had hypertension or diabetes as etiological factors for chronic kidney disease in these shifts. Fifteen of the patients were undergoing antihypertensive treatment with amlodipine, enalapril, metoprolol or prazosin. Additional drugs regularly used by some patients included sodium polystyrene sulfonate, sevelamer, clopidogrel, acetylsalicylic acid and famotidine. All patients received $5 \mathrm{mg}$ folate once weekly. Patients with diabetes were excluded. The regular examination of the patients did not reveal any sign of acute inflammation or systemic infection throughout the study.

The patients had been receiving epoetin beta twice weekly. As part of the treatment strategy, the latter 10 patients were to be switched to darbepoetin alfa, independently from the present study. Epoetin beta therapy was withdrawn for 14 days, after which ESA administration was resumed either with epoetin beta (11 patients, dose: 5000 IU twice a week), or with darbepoetin alfa (10 patients, dose: $50 \mu \mathrm{g}$ once weekly after the first dialysis of the week), administered in subcutaneous bolus injections at the end of the dialysis. If the transferrin saturation of a patient fell below 30\%, $62.5 \mathrm{mg}$ iron gluconate was given intravenously during each of five consecutive dialysis sessions. Written informed consent was obtained from the patients prior to their entering the study, approved by the Ethical Committee of the University of Szeged.

\subsection{Statistical analysis}

For Study 1, the clinical data on the patients and the results of the microvascular reactivity measurements and biochemical determinations are reported as medians (ranges). For Study 2, the clinical data on the patients and the results of the biochemical analyses are reported as means \pm SD. Statistical analyses were performed with GraphPad Prism 4.00 software (GraphPad Software Inc., La Jolla, CA, USA). Statistical comparisons included the nonparametric Kruskal-Wallis test, followed by Dunn's multiple comparison test (Study 1), or repeated-measures two-way analysis of variance (ANOVA), followed by Bonferroni's post hoc test (Study 2). For both studies, a $p$ value $<0.05$ was considered significant. 


\section{RESULTS}

\subsection{Microvascular reactivity in lean, overweight and obese hypertensive adolescents (Study 1)}

\subsubsection{Epidemiological and clinical data on the study groups}

The plasma levels of HDL cholesterol were significantly elevated in the LH group, and significantly decreased in the $\mathrm{OBH}$ patients (both $p<0.05$ vs the controls). The plasma triglyceride levels were higher in the $\mathrm{OWH}$ and $\mathrm{OBH}$ patients as compared with the controls ( $p<0.05$ and $p<0.01$, respectively). The plasma HDL cholesterol and triglyceride levels in the OBH group were also higher than those in the LH subjects ( $p<0.01$ and $p<0.05$, respectively). The mean age, diastolic BP and plasma levels of total and LDL cholesterol were similar in the study groups (Table 2).

\begin{tabular}{lc|c|c|c}
\multicolumn{1}{c|}{ Variables } & $\begin{array}{c}\text { Controls } \\
(\boldsymbol{n}=\mathbf{1 9})\end{array}$ & $\begin{array}{c}\text { Lean HT } \\
(\boldsymbol{n}=\mathbf{1 0})\end{array}$ & $\begin{array}{c}\text { Overweight HT } \\
(\boldsymbol{n}=\mathbf{1 3})\end{array}$ & $\begin{array}{c}\text { Obese HT } \\
(\boldsymbol{n}=\mathbf{1 0})\end{array}$ \\
\hline Age (yrs) & $15.4(15.2-16.0)$ & $16.5(7.0-18.5)$ & $15.3(9.8-18.7)$ & $14.2(7.0-18,9)$ \\
\hline Systolic BP (mmHg) & $115(105-120)$ & $144(125-160)^{* *}$ & $138(125-170)^{* *}$ & $140(125-150)^{*}$ \\
\hline Diastolic BP (mmHg) & $80(70-90)$ & $84(75-90)$ & $90(62-100)$ & $83(60-100)$ \\
\hline BMI (kg/m $)$ & $22.4(19.7-24.2)$ & $22.0(18.3-24.2)$ & $25.3(24.2-28.6)^{*, \dagger}$ & $30.9(23.0-38.2)^{* * *, \dagger \dagger \dagger}$ \\
\hline Total cholesterol (mmol/l) & $3.9(2.8-4.3)$ & $4.1(3.6-5.4)$ & $4.8(3.6-5.2)$ & $4.6(3.3-5.7)$ \\
\hline HDL cholesterol (mmol/l) & $1.5(1.2-1.8)$ & $1.9(1.4-2.1)^{*}$ & $1.4(0.9-1.7)^{\dagger}$ & $1.1(0.8-1.4)^{*, \dagger \dagger}$ \\
\hline LDL cholesterol (mmol/l) & $1.9(1.1-2.7)$ & $2.4(1.9-3.2)$ & $2.7(1.8-3.1)$ & $2.3(1.9-3.7)$ \\
\hline Triglycerides (mmol/l) & $0.7(0.4-1.0)$ & $0.7(0.4-1.1)$ & $0.9(0.6-3.1)^{*}$ & $1.2(0.9-3.0)^{* *, \dagger}$ \\
\hline
\end{tabular}

Table 2: Epidemiological and clinical parameters of the study groups (Study 1). Data are reported as medians (ranges). HT: hypertensive; BP: blood pressure; BMI: body mass index; HDL: high-density lipoprotein; LDL: low-density lipoprotein. Kruskal-Wallis test and Dunn's multiple comparison test. ${ }_{* * *} p<0.001,{ }^{* *} p<0.01,{ }^{*} p<0.05$ vs controls. ${ }^{\dagger \dagger} p<0.001,{ }^{\dagger \dagger} p<0.01,{ }^{\dagger} p<0.05$ vs lean HT. 


\subsubsection{Biochemical parameters}

Results of the biochemical analyses are summarized in Table 3. The whole blood ratios GSSG/GSH were significantly elevated in all the patient groups (all $p<0.001 v s$ the controls). Also, the ratios GSSG/GSH in the OBH group were higher than those in the LH subjects $(p<0.05)$. The activities of E-CAT were increased in the OWH group as compared with the controls $(p<0.05)$. The levels of plasma alfa-tocopherol (relative to the total cholesterol plus triglyceride levels) and E-MDA, and the activities of E-SOD were similar in the study groups.

\begin{tabular}{lc|c|c|c}
\multicolumn{1}{c}{ Variables } & $\begin{array}{c}\text { Controls } \\
(\boldsymbol{n}=\mathbf{1 9})\end{array}$ & $\begin{array}{c}\text { Lean HT } \\
(\boldsymbol{n = 1 0})\end{array}$ & $\begin{array}{c}\text { Overweight HT } \\
(\boldsymbol{n}=\mathbf{1 3})\end{array}$ & $\begin{array}{c}\text { Obese HT } \\
(\boldsymbol{n}=\mathbf{1 0})\end{array}$ \\
\hline GSSG/GSH (\%) & $0.144(0.071-0.201)$ & $0.322(0.163-0.379)$ & $0.314(0.203-0.401)^{* * * *}$ & $\begin{array}{c}0.367 \\
(0.311-0.441)^{* * *}, \dagger\end{array}$ \\
\hline $\begin{array}{l}\text { Plasma alfa-tocopherol/ } \\
\text { /(total cholesterol plus } \\
\text { triglycerides) } * \mathbf{1 0}^{-3}\end{array}$ & $3.1(2.6-4.1)$ & $3.0(2.4-3.8)$ & $2.8(2.3-3.4)$ & $2.8(2.6-3.3)$ \\
\hline E-MDA (nmol/g Hb) & $5.1(3.2-8.6)$ & $6.2(5.4-8.0)$ & $4.9(3.6-6.1)$ & $5.5(3.0-8.0)$ \\
\hline E-SOD (U/mg prot) & $3.7(3.0-4.0)$ & $3.7(1.0-4.1)$ & $3.4(2.4-4.2)$ & $3.2(2.2-5.3)$ \\
\hline E-CAT (BU/mg prot*10 $\left.\mathbf{1 0}^{-3}\right)$ & $1.1(1.0-1.6)$ & $1.4(1.0-1.9)$ & $1.6(1.1-2.1)^{*}$ & $1.4(0.8-1.8)$ \\
\hline
\end{tabular}

Table 3: Oxidative stress markers in the study groups (Study 1). Data are reported as medians (ranges). HT: hypertensive; GSSG/GSH: whole blood ratio of oxidized/reduced glutathione; E-MDA: erythrocyte malondialdehyde; E-SOD: erythrocyte superoxide dismutase; E-CAT: erythrocyte catalase; Hb: hemoglobin. Kruskal-Wallis test and Dunn's multiple comparison test. ${ }^{* * *} p<0.001,{ }^{*} p<0.05$ vs controls. ${ }^{\dagger} p<0.05$ vs lean HT.

\subsubsection{Laser Doppler flowmetry}

The perfusion increments after iontophoresis of the endothelium-dependent vasodilator $\mathrm{ACH}$ did not differ significantly in the patient groups and the controls (Table 4, Figure 5A). In contrast, the second iontophoretic dose of the endothelium-independent vasodilator SNP increased the microvascular blood flux to a significantly smaller extent in the LH group than in the controls $(p<0.05)$. After the third SNP dose, similar differences were revealed in the LH and the OBH groups as compared with the controls (both $p<0.05$ ) (Table 5, Figure 5B). 
In response to local heating to $44{ }^{\circ} \mathrm{C}$, the increase in the microvascular perfusion attained a plateau at similar relative flux values at site 1 in all groups (Table 4, Figure 5A). At site 2, significantly smaller flux increments were detected in the LH and the OBH groups than in the controls (Table 5, Figure 5B). The study protocol was well tolerated by all subjects and no adverse local or systemic effects were observed.

\begin{tabular}{|c|c|c|c|c|}
\hline & $\begin{array}{c}\text { Controls } \\
(n=19)\end{array}$ & $\begin{array}{c}\text { Lean HT } \\
(n=10)\end{array}$ & $\begin{array}{c}\text { Overweight HT } \\
(n=13)\end{array}$ & $\begin{array}{c}\text { Obese HT } \\
(n=10)\end{array}$ \\
\hline $1^{\text {st }} \mathrm{ACH}$ iontophoresis & $\begin{array}{c}367.0 \\
(100.0-499.0)\end{array}$ & $\begin{array}{c}110.0 \\
(100.0-1134.0)\end{array}$ & $\begin{array}{c}123.5 \\
(100.0-856.0)\end{array}$ & $\begin{array}{c}267.0 \\
(100.0-364.0)\end{array}$ \\
\hline $2^{\text {nd }} \mathrm{ACH}$ iontophoresis & $\begin{array}{c}860.0 \\
(150.0-1854.0)\end{array}$ & $\begin{array}{c}420.5 \\
(268.0-1465.0)\end{array}$ & $\begin{array}{c}578.5 \\
(264.0-1935.0)\end{array}$ & $\begin{array}{c}526.0 \\
(333.0-909.0)\end{array}$ \\
\hline $3^{\text {rd }} \mathrm{ACH}$ iontophoresis & $\begin{array}{c}1339.0 \\
(577.0-2187.0)\end{array}$ & $\begin{array}{c}889.0 \\
(730.0-2368.0)\end{array}$ & $\begin{array}{c}1037.0 \\
(380.0-2210.0)\end{array}$ & $\begin{array}{c}994.5 \\
(884.0-1492.0)\end{array}$ \\
\hline Local heating to $44^{\circ} \mathrm{C}$ (site 1$)$ & $\begin{array}{c}2087.0 \\
(909.0-3245.0)\end{array}$ & $\begin{array}{c}1687.0 \\
(1068.0-3230.0)\end{array}$ & $\begin{array}{c}1534.0 \\
(836.0-2741.0)\end{array}$ & $\begin{array}{c}1576.0 \\
(1058.0-2137.0)\end{array}$ \\
\hline
\end{tabular}

Table 4: Skin blood flux values in response to three doses of acetylcholine iontophoresis and local heating to $44{ }^{\circ} \mathbf{C}$ (site 1, Study 1). Data are reported as medians (ranges). HT: hypertensive; ACH: acetylcholine. Kruskal-Wallis test and Dunn's multiple comparison test.

\begin{tabular}{lc|c|c|c} 
& $\begin{array}{c}\text { Controls } \\
(\boldsymbol{n}=\mathbf{1 9})\end{array}$ & $\begin{array}{c}\text { Lean HT } \\
(\boldsymbol{n}=\mathbf{1 0})\end{array}$ & $\begin{array}{c}\text { Overweight HT } \\
(\boldsymbol{n}=\mathbf{1 3})\end{array}$ & $\begin{array}{c}\text { Obese HT } \\
(\boldsymbol{n}=\mathbf{1 0})\end{array}$ \\
\hline $\mathbf{1}^{\text {st }} \mathbf{S N P}$ iontophoresis & $\begin{array}{c}341.0 \\
(100.0-1131.0)\end{array}$ & $\begin{array}{c}110.0 \\
(100.0-949.0)\end{array}$ & $\begin{array}{c}426.5 \\
(100.0-897.0)\end{array}$ & $\begin{array}{c}361.5 \\
(164.0-774.0)\end{array}$ \\
\hline $\mathbf{2}^{\text {nd }} \mathbf{S N P}$ iontophoresis & $\begin{array}{c}847.0 \\
(432.0-1708.0)\end{array}$ & $\begin{array}{c}482.5 \\
(157.0-842.0)^{*}\end{array}$ & $\begin{array}{c}776.5 \\
(170.0-1494.0)\end{array}$ & $\begin{array}{c}655.5 \\
(240.0-1204.0)\end{array}$ \\
\hline $\mathbf{3}^{\text {rd }} \mathbf{S N P}$ iontophoresis & 1195.0 & 797.5 & 1078.0 & 744.0 \\
\hline Local heating to $\mathbf{4 4}{ }^{\circ} \mathbf{C}$ (site 2) & $(1074.0-1774.0)$ & $(270.0-1100.0)^{*}$ & $(333.0-1618.0)$ & $(390.0-1207.0)^{*}$ \\
\hline & 1870.0 & 1257.0 & 1682.0 & 1188.0 \\
\end{tabular}

Table 5: Skin blood flux values in response to three doses of sodium nitroprusside iontophoresis and local heating to $44^{\circ} \mathrm{C}$ (site 2, Study 1). Data are reported as medians (ranges). HT: hypertensive; SNP: sodium nitroprusside. Kruskal-Wallis test and Dunn's multiple comparison test. " $p<0.05 v s$ controls. 

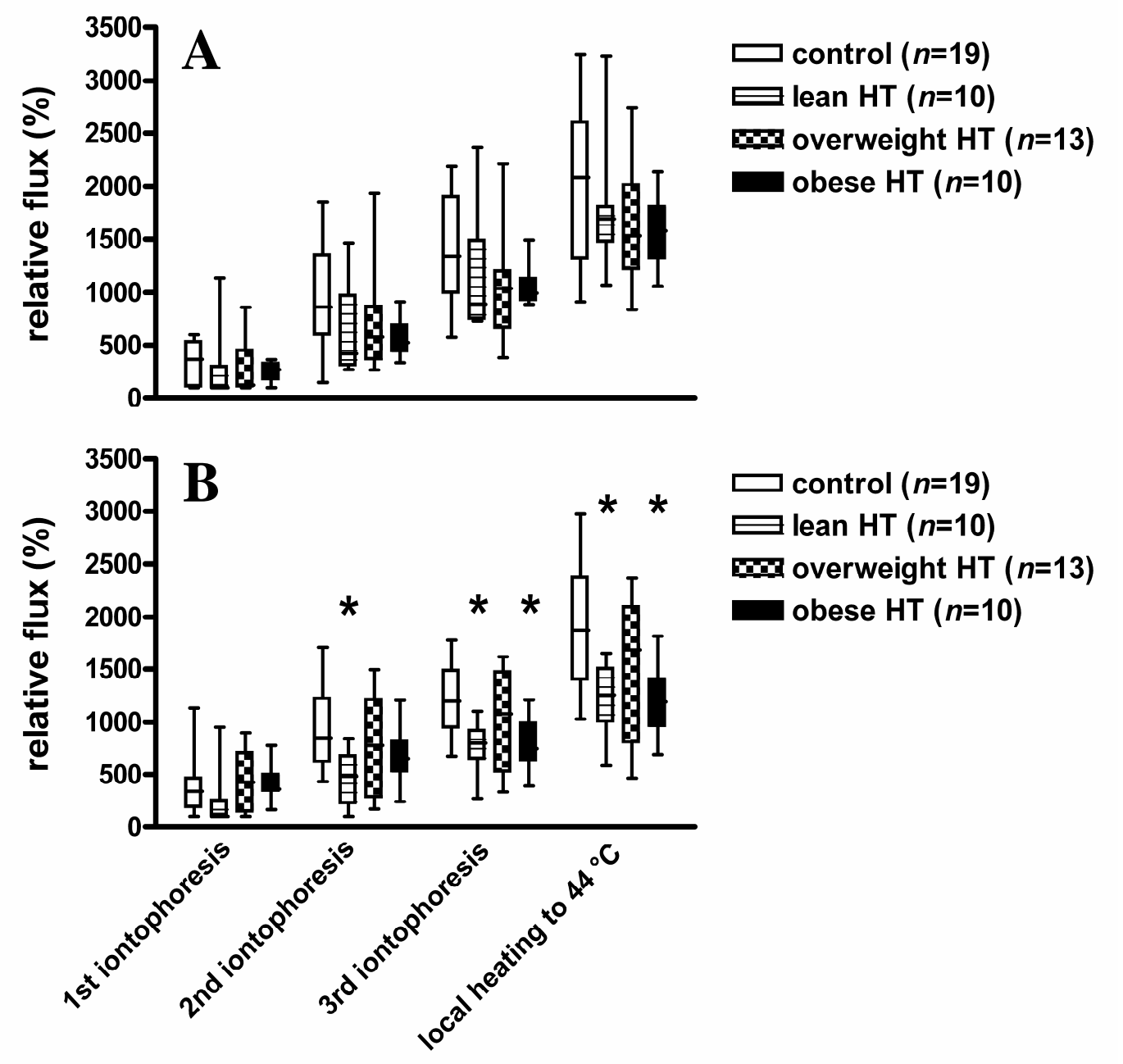

Figure 5: Changes in skin blood flux in response to three doses of acetylcholine [part A, site 1] and sodium nitroprusside [part B, site 2] iontophoresis and local heating to $44^{\circ} \mathrm{C}$ (Study 1). Empty box: control group; striped box: lean hypertensives; squared box: overweight hypertensives; filled box: obese hypertensives. Data are expressed relative to the baseline values (medians (ranges), baseline=100\%). HT: hypertensive. Kruskal-Wallis test and Dunn's multiple comparison test. " $p<0.05$ vs controls. 


\subsection{Erythropoiesis-stimulating agent withdrawal and oxidative stress in hemodialysis (Study 2)}

\subsubsection{Hematological indices}

The Hb levels were decreased at week 6 in both groups ( $p<0.05 v s$ the baseline), and had returned to the initial values by week 14 (Table 6). The proportion of reticulocytes exhibited a decrease at week 2 and a subsequent elevation at weeks 6 and 10 (all $p<0.05 v s$ the baseline) (Table 6). No differences were observed between the groups in either parameter. The transferrin saturation values and the levels of ferritin were not changed in either group (Table 6).

\begin{tabular}{|c|c|c|c|c|c|c|c|c|c|}
\hline & & \multirow{2}{*}{$\begin{array}{l}\text { Base- } \\
\text { line }\end{array}$} & \multirow{2}{*}{$\begin{array}{c}\text { Week } \\
2\end{array}$} & \multirow{2}{*}{$\begin{array}{c}\text { Week } \\
6\end{array}$} & \multirow{2}{*}{$\begin{array}{c}\text { Week } \\
10\end{array}$} & \multirow{2}{*}{$\begin{array}{c}\text { Week } \\
14\end{array}$} & \multicolumn{3}{|c|}{ Repeated-measures two-way ANOVA } \\
\hline & & & & & & & $\begin{array}{l}p \text { value for } \\
\text { interaction }\end{array}$ & $\begin{array}{l}p \text { value for } \\
\text { factor } \\
\text { "drug" }\end{array}$ & $\begin{array}{l}p \text { value for } \\
\text { factor } \\
\text { "time" }\end{array}$ \\
\hline \multirow{2}{*}{$\begin{array}{l}\text { Hemoglobin } \\
(\mathrm{g} / \mathrm{l})\end{array}$} & $\begin{array}{l}\text { Darbepoetin } \\
\text { alfa }\end{array}$ & $\begin{array}{c}114.1 \pm \\
8.6\end{array}$ & $\begin{array}{c}111.9 \pm \\
12.8\end{array}$ & $\begin{array}{c}101.6 \pm \\
13.0\end{array}$ & $\begin{array}{c}103.4 \pm \\
10.5\end{array}$ & $\begin{array}{c}116.6 \pm \\
11.0\end{array}$ & \multirow{2}{*}{ n.s. } & \multirow{2}{*}{ n.s. } & \multirow{2}{*}{$<0.05$} \\
\hline & Epoetin beta & $\begin{array}{c}120.9 \pm \\
14.2\end{array}$ & $\begin{array}{c}107.3 \pm \\
20.4\end{array}$ & $\begin{array}{c}103.0 \pm \\
16.1\end{array}$ & $\begin{array}{c}109.9 \pm \\
17.3\end{array}$ & $\begin{array}{c}114.3 \pm \\
17.6\end{array}$ & & & \\
\hline \multirow{2}{*}{$\begin{array}{l}\text { Proportion of } \\
\text { reticulocytes } \\
(\% o)\end{array}$} & $\begin{array}{l}\text { Darbepoetin } \\
\text { alfa }\end{array}$ & $\begin{array}{c}10.3 \pm \\
4.2\end{array}$ & $\begin{array}{l}7.6 \pm \\
1.3\end{array}$ & $\begin{array}{c}14.0 \pm \\
7.7\end{array}$ & $\begin{array}{c}14.4 \pm \\
6.8\end{array}$ & $\begin{array}{c}13.7 \pm \\
3.1\end{array}$ & \multirow{2}{*}{ n.s. } & \multirow{2}{*}{ n.s. } & \multirow{2}{*}{$<0.001$} \\
\hline & Epoetin beta & $\begin{array}{c}11.5 \pm \\
4.2\end{array}$ & $\begin{array}{c}6.8 \pm \\
2.2\end{array}$ & $\begin{array}{c}13.9 \pm \\
3.9\end{array}$ & $\begin{array}{c}16.4 \pm \\
4.3\end{array}$ & $\begin{array}{l}12.3 \pm \\
5.5\end{array}$ & & & \\
\hline \multirow{2}{*}{$\begin{array}{l}\text { Transferrin } \\
\text { saturation }(\%)\end{array}$} & $\begin{array}{l}\text { Darbepoetin } \\
\text { alfa }\end{array}$ & $\begin{array}{l}38.1 \pm \\
25.5\end{array}$ & $\begin{array}{l}37.9 \pm \\
28.9\end{array}$ & $\begin{array}{c}34.9 \pm \\
9.9\end{array}$ & $\begin{array}{c}34.3 \pm \\
9.9\end{array}$ & $\begin{array}{c}34.1 \pm \\
14.4\end{array}$ & \multirow{2}{*}{ n.s. } & \multirow{2}{*}{ n.s. } & \multirow{2}{*}{ n.s. } \\
\hline & Epoetin beta & $\begin{array}{c}39.3 \pm \\
17.1\end{array}$ & $\begin{array}{l}55.4 \pm \\
23.8\end{array}$ & $\begin{array}{c}42.6 \pm \\
27.9\end{array}$ & $\begin{array}{l}29.1 \pm \\
8.3\end{array}$ & $\begin{array}{c}49.0 \pm \\
24.5\end{array}$ & & & \\
\hline \multirow{2}{*}{$\begin{array}{l}\text { Ferritin } \\
(\mathbf{n g} / \mathrm{ml})\end{array}$} & $\begin{array}{l}\text { Darbepoetin } \\
\text { alfa }\end{array}$ & - & $\begin{array}{c}793.5 \pm \\
653.3\end{array}$ & - & - & $\begin{array}{c}687.0 \pm \\
468.8\end{array}$ & \multirow{2}{*}{ n.s. } & \multirow{2}{*}{ n.s. } & \multirow{2}{*}{ n.s. } \\
\hline & Epoetin beta & - & $\begin{array}{c}808.6 \pm \\
465.4\end{array}$ & - & - & $\begin{array}{c}758.4 \pm \\
529.0\end{array}$ & & & \\
\hline
\end{tabular}

Table 6: Hematological parameters in the study groups (Study 2). The antecedent epoetin beta therapy was withdrawn between week 0 (baseline) and week 2. Data are presented as means \pm SD. n.s.: nonsignificant. Repeated-measures two-way ANOVA and Bonferroni's post hoc test. 


\subsubsection{Biochemical parameters}

The ratios GSSG/GSH were significantly increased at weeks 2 and 6 in both groups (all $p<0.001 v s$ the baseline), but had returned to the initial levels by week 14 (Figure 6). Similar tendencies were found in the levels of GSSG (Table 7). The GSH concentrations were increased at week 14 in the two groups ( $p<0.001$ vs the baseline) (Table 7). The E-MDA levels exhibited an elevation at week $6(p<0.01 v s$ the baseline) and a subsequent return to the initial levels by week 14 in both groups (Table 7). As compared with the baseline values, the activities of E-SOD were reduced significantly at week 6 in both study groups $(p<0.001)$, and had returned to the baseline by week 14 (Table 7). The activities of E-CAT were significantly increased at week 14 in both groups ( $p<0.001 v s$ the baseline) (Table 7).

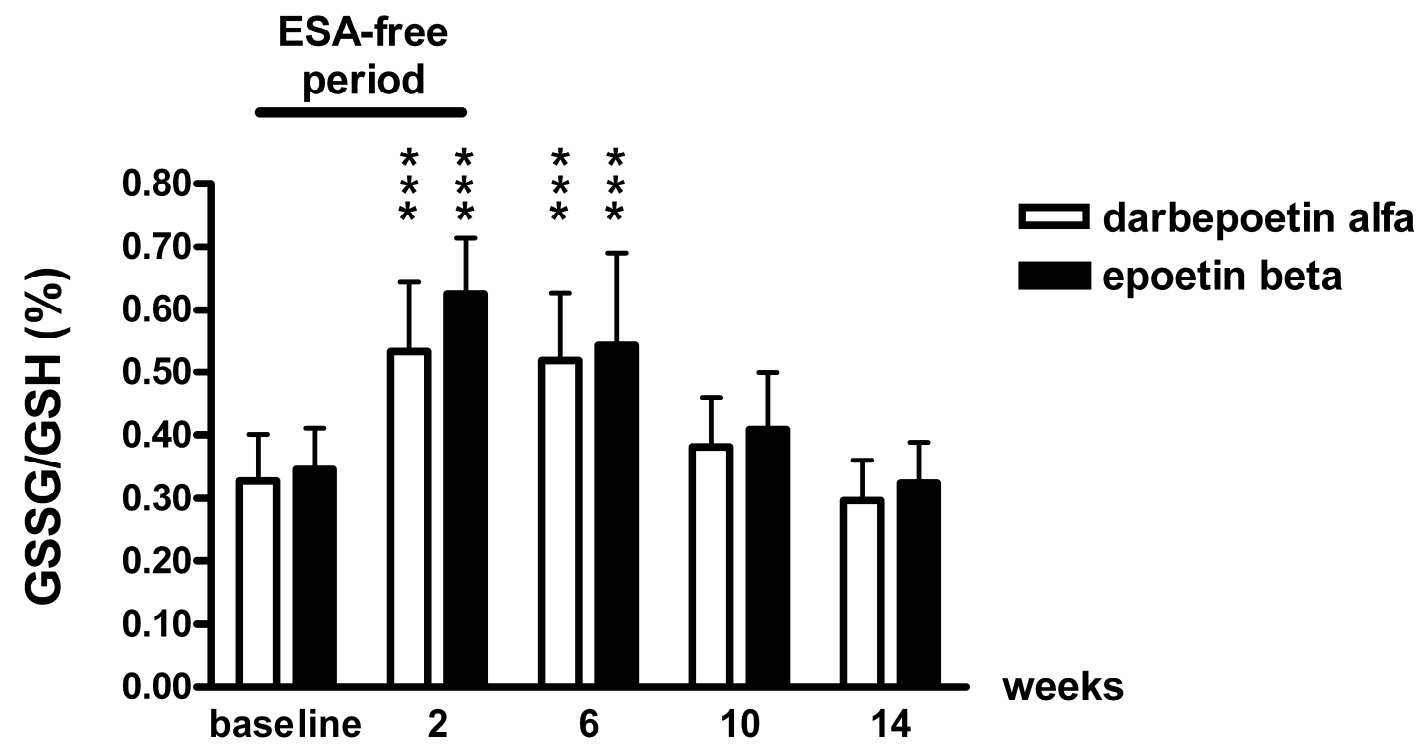

Figure 6: Whole blood oxidized/reduced glutathione ratios (GSSG/GSH) (Study 2). The antecedent epoetin beta therapy was withdrawn between week 0 (baseline) and week 2. Empty columns: darbepoetin alfa; filled columns: epoetin beta. Data are expressed as means \pm SD. ESA: Erythropoiesis-stimulating agent. Repeated-measures two-way ANOVA and Bonferroni's post hoc test: *** $p<0.001 v s$ baseline (factor "time") and $p=$ nonsignificant for both interaction and factor "drug". 


\begin{tabular}{|c|c|c|c|c|c|c|c|c|c|}
\hline & & \multirow{2}{*}{$\begin{array}{l}\text { Base- } \\
\text { line }\end{array}$} & \multirow{2}{*}{$\begin{array}{c}\text { Week } \\
2\end{array}$} & \multirow{2}{*}{$\begin{array}{l}\text { Week } \\
6\end{array}$} & \multirow{2}{*}{$\begin{array}{c}\text { Week } \\
10\end{array}$} & \multirow[b]{2}{*}{$\begin{array}{c}\text { Week } \\
14\end{array}$} & \multicolumn{3}{|c|}{ Repeated-measures two-way ANOVA } \\
\hline & & & & & & & $\begin{array}{l}p \text { value for } \\
\text { interaction }\end{array}$ & $\begin{array}{l}p \text { value for } \\
\text { factor } \\
\text { "drug" }\end{array}$ & $\begin{array}{c}p \text { value for } \\
\text { factor } \\
\text { "time" }\end{array}$ \\
\hline \multirow{2}{*}{$\begin{array}{l}\text { GSSG } \\
(\mathrm{nmol} / \mathrm{g} \mathrm{Hb})\end{array}$} & $\begin{array}{l}\text { Darbepoetin } \\
\text { alfa }\end{array}$ & $\begin{array}{c}25.9 \pm \\
6.5\end{array}$ & $\begin{array}{c}43.6 \pm \\
10.7\end{array}$ & $\begin{array}{l}44.6 \pm \\
9.6\end{array}$ & $\begin{array}{c}34.2 \pm \\
9.4\end{array}$ & $\begin{array}{c}28.8 \pm \\
4.7\end{array}$ & \multirow{2}{*}{ n.s. } & \multirow{2}{*}{ n.s. } & \multirow{2}{*}{$<0.001$} \\
\hline & Epoetin beta & $\begin{array}{c}24.3 \pm \\
4.4\end{array}$ & $\begin{array}{c}44.2 \pm \\
9.0\end{array}$ & $\begin{array}{c}41.8 \pm \\
9.8\end{array}$ & $\begin{array}{c}32.6 \pm \\
4.9\end{array}$ & $\begin{array}{c}29.1 \pm \\
4.9\end{array}$ & & & \\
\hline \multirow{2}{*}{$\begin{array}{l}\text { GSH } \\
(\mu \mathrm{mol} / \mathrm{g} \mathrm{Hb})\end{array}$} & $\begin{array}{l}\text { Darbepoetin } \\
\text { alfa }\end{array}$ & $\begin{array}{c}7.9 \pm \\
1.2\end{array}$ & $\begin{array}{c}8.2 \pm \\
1.5\end{array}$ & $\begin{array}{c}8.7 \pm \\
2.1\end{array}$ & $\begin{array}{c}9.1 \pm \\
2.0\end{array}$ & $\begin{array}{c}10.0 \pm \\
1.9\end{array}$ & \multirow{2}{*}{ n.s. } & \multirow{2}{*}{ n.s. } & \multirow{2}{*}{$<0.001$} \\
\hline & Epoetin beta & $\begin{array}{c}7.2 \pm \\
1.6\end{array}$ & $\begin{array}{c}7.1 \pm \\
1.6\end{array}$ & $\begin{array}{c}7.8 \pm \\
1.1\end{array}$ & $\begin{array}{c}8.1 \pm \\
1.2\end{array}$ & $\begin{array}{c}9.1 \pm \\
1.5\end{array}$ & & & \\
\hline \multirow{2}{*}{$\begin{array}{l}\text { E-MDA } \\
(\mathbf{n m o l} / \mathbf{g} \text { Hb) }\end{array}$} & $\begin{array}{l}\text { Darbepoetin } \\
\text { alfa }\end{array}$ & $\begin{array}{c}12.3 \pm \\
1.9\end{array}$ & $\begin{array}{c}13.1 \pm \\
1.2\end{array}$ & $\begin{array}{c}14.0 \pm \\
1.4\end{array}$ & $\begin{array}{c}13.2 \pm \\
1.1\end{array}$ & $\begin{array}{c}12.0 \pm \\
1.5\end{array}$ & \multirow{2}{*}{ n.s. } & \multirow{2}{*}{ n.s. } & \multirow{2}{*}{$<0.01$} \\
\hline & Epoetin beta & $\begin{array}{c}11.8 \pm \\
1.1\end{array}$ & $\begin{array}{c}12.2 \pm \\
1.2\end{array}$ & $\begin{array}{c}13.4 \pm \\
1.0\end{array}$ & $\begin{array}{c}12.5 \pm \\
1.3\end{array}$ & $\begin{array}{c}12.4 \pm \\
1.1\end{array}$ & & & \\
\hline \multirow{2}{*}{$\begin{array}{l}\text { E-SOD activity } \\
\text { (U/mg protein) }\end{array}$} & $\begin{array}{l}\text { Darbepoetin } \\
\text { alfa }\end{array}$ & $\begin{array}{c}3.3 \pm \\
0.6\end{array}$ & $\begin{array}{c}3.4 \pm \\
0.8\end{array}$ & $\begin{array}{c}2.6 \pm \\
0.3\end{array}$ & $\begin{array}{c}3.3 \pm \\
0.4\end{array}$ & $\begin{array}{c}3.0 \pm \\
0.4\end{array}$ & \multirow{2}{*}{ n.s. } & \multirow{2}{*}{$<0.05$} & \multirow{2}{*}{$<0.001$} \\
\hline & Epoetin beta & $\begin{array}{c}3.8 \pm \\
0.6\end{array}$ & $\begin{array}{c}3.2 \pm \\
0.2\end{array}$ & $\begin{array}{c}3.0 \pm \\
0.7\end{array}$ & $\begin{array}{c}3.5 \pm \\
0.2\end{array}$ & $\begin{array}{c}3.6 \pm \\
0.2\end{array}$ & & & \\
\hline \multirow{2}{*}{$\begin{array}{l}\text { E-CAT activity } \\
(\text { BU/mg protein } \\
\left.* 10^{-3}\right)\end{array}$} & $\begin{array}{l}\text { Darbepoetin } \\
\text { alfa }\end{array}$ & $\begin{array}{c}1.1 \pm \\
0.4\end{array}$ & $\begin{array}{c}1.3 \pm \\
0.4\end{array}$ & $\begin{array}{c}0.9 \pm \\
0.2\end{array}$ & $\begin{array}{c}1.1 \pm \\
0.1\end{array}$ & $\begin{array}{c}1.6 \pm \\
0.3\end{array}$ & \multirow{2}{*}{ n.s. } & \multirow{2}{*}{ n.s. } & \multirow{2}{*}{$<0.001$} \\
\hline & Epoetin beta & $\begin{array}{c}1.0 \pm \\
0.4\end{array}$ & $\begin{array}{c}1.1 \pm \\
0.2\end{array}$ & $\begin{array}{c}0.9 \pm \\
0.2\end{array}$ & $\begin{array}{c}1.1 \pm \\
0.1\end{array}$ & $\begin{array}{c}1.5 \pm \\
0.3\end{array}$ & & & \\
\hline
\end{tabular}

Table 7: Oxidative parameters in the study groups (Study 2). The antecedent epoetin beta therapy was withdrawn between week 0 (baseline) and week 2. Data are presented as means \pm SD. GSSG: whole blood oxidized glutathione; GSH: whole blood reduced glutathione; E-MDA: erythrocyte malondialdehyde; E-SOD: erythrocyte superoxide dismutase; E-CAT: erythrocyte catalase; Hb: hemoglobin; n.s.: nonsignificant. Repeated-measures two-way ANOVA and Bonferroni's post hoc test. 


\section{DISCUSSION}

Cardiovascular risk factors such as hypertension, obesity and uremia are accompanied by the loss of endothelium-derived vasodilator and anti-thrombotic factors, and increased levels of inflammatory and oxidative stress markers in adults $[7,115]$. Target-organ damage such as left ventricular hypertrophy or an increased carotid artery intima-media thickness can be present already in childhood $[9,10,15]$, although there are at present no long-term data to link a level of childhood BP with cardiovascular events in later adulthood. The prevalence of hypertension in childhood and adolescence (about 3\% in 2006 [116]) is showing an increasing trend, which is in part attributable to the high prevalence of obesity [9, 10, 15]. BP [117] and weight [118] show tracking from childhood into adulthood, which further emphasizes the importance of juvenile hypertension and overweight. Even if secondary causes of the BP elevation can be revealed in some hypertensive patients, late in the first decade of life and throughout the second, primary hypertension becomes the most common cause of sustained hypertension, particularly in those children with mild asymptomatic disease [9].

\subsection{Microvascular reactivity in lean, overweight and obese hypertensive adolescents (Study 1)}

To the best of our knowledge, this study was the first to assess the functional properties of the microvessels in juvenile primary hypertension. Moreover, a comparison of the microvascular reactivities of hypertensive adolescents grouped according to the degree of ponderosity (LH, OWH and $\mathrm{OBH}$ patients) was performed.

The microvascular responses to iontophoresis of the endothelium-dependent vasodilator $\mathrm{ACH}$ and local heating (site 1) were not significantly attenuated in these hypertensive groups (irrespective of the BMI) as compared with the controls (Table 4, Figure 5A). The endothelium-independent vasodilation in response to SNP iontophoresis was impaired to a similar degree in the LH and OBH patients, but not in the OWH adolescents (Table 5, Figure 5B). It was an interesting finding that local skin heating was associated with distinct responses when performed after either the ACH or SNP iontophoresis sequence (sites 1 and 2, 
respectively). Local skin warming initiates a biphasic response: an initial rapid increase to a peak, mediated by neurotransmitter release from sensory afferents, followed by a prolonged plateau phase, predominantly mediated by NO generation [119]. This, in turn, raises the possibility of using the local thermal hyperemia test as a tool with which to assess the endothelium-dependent microvascular function [102]. In accordance, similar blood flux responses were observed to $\mathrm{ACH}$ iontophoresis and local heating at site 1 in our study. The different responses to local heating at site 2 were presumably influenced by the slower clearance of SNP as compared with $\mathrm{ACH}$, as indicated by the reported time-response curves of the drugs [120] and the higher flux values at site 2 at the start of the heating test in the present study, as compared with those at site 1 (data not shown).

During the validation stage of Study 1, a markedly attenuated function of the microvascular system, both endothelium-dependent and -independent, was found in the HD patients. Moreover, a greatly increased oxidative stress was confirmed by elevated levels of E-MDA, GSSG and GSSG/GSH, and decreased concentrations of GSH (data not published). All changes were much more pronounced in the HD group than those in the hypertensives. Even if these findings are in agreement with previous observations [52, 56, 95-97], the mechanisms of these alterations and their possible relationship have not been fully elucidated. Further analysis of the HD group revealed that the most noteworthy variance among the patients was the difference in the ESA therapy. These observations led us to the assumption that characteristics of the ESA therapy and/or variances in the action of ESA may contribute to the alterations described above. Therefore, the aims of our second study were to examine the influence of the short-term withdrawal of ESA therapy on oxidative parameters in HD patients; and to follow the changes in oxidative stress after therapy resumption with two commonly used ESAs, darbepoetin alfa and epoetin beta. 


\subsection{Erythropoiesis-stimulating agent withdrawal and oxidative stress in hemodialysis (Study 2)}

This study was the first to reveal alterations in oxidative stress, as shown by increased ratios GSSG/GSH, after the interruption of epoetin beta treatment in HD patients (Figure 6). Four weeks after either darbepoetin alfa or epoetin beta readministration (week 6), significantly elevated GSSG/GSH, GSSG and E-MDA levels, and decreased activities of E-SOD were found as compared with the respective baseline values (Table 4). These findings are in line with previous reports of a transiently increased oxidative stress after the initiation of epoetin alfa treatment (culminating at week 4 of the therapy) [60], an impairment of the antioxidant defense after ESA withdrawal [122], and elevations in the levels of circulating inflammatory markers after 4 weeks of ESA therapy [123]. By the end of the 14-week study, all parameters had returned to the respective initial values. The GSH and E-CAT activity levels at week 14 were higher than initially in both groups (Table 4), concordant with the reported adaptive response of the glutathione redox system to oxidative stress [1, 124], consisting of augmented GSH regeneration and synthesis.

\subsection{Possible mechanisms and clinical significance of the findings}

Controversies exist as to whether the development of a vascular dysfunction precedes or follows the elevation of the BP. The endothelial function in normotensive offsprings of hypertensive patients has been reported to be impaired [125, 126], although not consistently [127] (this issue has been previously reviewed [128]). This would suggest that an endothelial dysfunction might precede the development of hypertension. However, none of these studies were prospective, and adolescents were enrolled in only one study assessing brachial artery FMD [125]. On the other hand, a decreased vascular function may develop as a consequence of the elevated BP. Transient hypertension has been shown to give rise to a direct attenuation of the endothelium-dependent vasodilation of the human microvasculature in vitro [129]. In the Cardiovascular Risk in Young Finns Study, an elevated systolic BP in male adolescents was found to predict an impaired brachial artery FMD in adulthood [130]. However, there 
have been no reports as concerns endothelium-dependent and -independent reactivities of the microvascular system in adolescents.

Our finding of a preserved endothelium-dependent microvascular reactivity in hypertensive adolescents (Figure 5A) may seem to contradict previous reports of a diminished availability of $\mathrm{NO}$ in this patient group $[43,131]$. $\mathrm{ACH}$ iontophoresis releases $\mathrm{NO}$, prostanoids and other vasoactive substances in the microvessels [132]. The compensatory activities of vasoactive mechanisms other than NO could prevent an impairment of the endothelium-dependent microvascular reactivity despite decreased NO levels. In accordance, prostanoids contribute to the vasodilator response to $\mathrm{ACH}$ to a greater extent in healthy young adults than in older subjects [133]. Taken together, these findings suggest that, in the pathogenesis of juvenile primary hypertension, an impairment of the endothelium-dependent microvascular reactivity is more likely to follow, rather than precede the elevation of the BP.

The responses to the endothelium-independent vasodilator SNP were found to be attenuated in the $\mathrm{LH}$ and $\mathrm{OBH}$ groups, but not in the $\mathrm{OWH}$ adolescents (Figure 5B). This result is in line with the hypothesis that the cardiovascular risk of OWH patients might be more favorable than that of their LH counterparts [134], as suggested by several [135, 136], albeit not all [137] studies. In contrast with the present findings, the endothelium-independent microvascular reactivity has been reported to be preserved in adult hypertensives [98, 99]. The different microvascular responses among the patient groups in Study 1 were not related to variances in the levels of oxidative markers, suggesting that factors other than oxidative stress play roles. SNP is an NO donor that reacts with tissue sulfhydryl groups under physiological conditions to produce NO directly and thereby stimulate smooth muscle relaxation [91]. The decomposition of SNP, the rate of NO liberation and consequently the effects of SNP iontophoresis on smooth muscle cells may be influenced by the local temperature, the abundance of tissue sulfhydryl groups, and the tissue oxygen tension and $\mathrm{pH}[138,139]$. Even if we standardized the local skin temperature during the iontophoresis sequence, the possible influences of the latter factors on the endothelium-independent microvascular responses cannot be excluded.

One may speculate that the microvascular responses reported here might have been influenced by individual differences in skin thickness, especially in obese subjects. Skin resistance is indeed an important factor that affects the delivery of vasoactive ions and 
consequently the reactivity of the microvessels, as described by Ramsay et al. [140]. The MIC2 Iontophoresis Device used in the present study automatically modifies the applied voltage as a function of skin resistance, so that the current and the delivery of ions into the skin remain constant. Thus, individual differences in skin resistance are not likely to have had a substantial effect on the microvascular responses.

As to the microvascular function in the HD group, both the endothelium-dependent and -independent reactivities were markedly attenuated. Oxidative stress is a potential cause of the impaired vascular function in HD patients, characterized by increased levels of oxidative markers, a compromised antioxidant protection [7, 52], and periodical exogenous challenges that reportedly affect oxidative stress, such as the HD sessions [7,50,51] and the administrations of intravenous iron [50, 105] and ESA [67]. Although effects of the HD sessions and intravenous iron on oxidative markers have already been explored $[7,50,51,105]$, the issue of ESA therapy has not yet been fully elucidated. The episodic administration of ESA is in contrast with the smoother physiological changes in the endogenous erythropoietin (EPO) levels [121]. Elevations and descents may be observed in the plasma level of ESA between individual doses, despite unaltered Hb levels [121]. This, in turn, could have an influence on the reported antioxidant effect of the ESA treatment [67], so that the antioxidant protection would be transiently attenuated if the level of ESA declined. Such fluctuations in the antioxidant protection would add to the repeated effects of HD sessions on the oxidative stress and the microvasculature [50,51, 141]. Possible clinical examples are the late phase of the widely extended administration intervals, and the temporary suspension of ESA therapy in consequence of the guideline $\mathrm{Hb}$ level being exceeded, conditions in which the action of ESA may be depressed [121]. To assess the hypothesis that variances in the action of ESA contribute to an alteration in the oxidative stress, we studied the effects of a 14-day suspension of ESA therapy on oxidative indices.

Directly after ESA withholding (Study 2), a marked increase in the ratio GSSG/GSH was revealed in HD patients (Figure 6). In terms of mechanisms that may contribute to this elevation, we first refer to the earlier study of Rice et al. [142], who reported that ESA therapy withdrawal induces hemolysis of the young red blood cells (RBCs) in renal failure [142]. Although we did not assess neocytolysis directly, a higher elimination rate of young erythrocytes could contribute to an increase in the ratio GSSG/GSH, due to low GSSG and 
high GSH contents of young RBCs [143] and the release of free heme, promoting the oxidation of lipids and membrane-bound proteins [144]. However, the proposed theory of the mechanism of neocytolysis, which suggested the existence of an EPO-mediated endothelial cell-macrophage interaction [121], has been questioned by recent reports of an absence of EPO receptors on endothelial cells [145, 146].

Secondly, ESA withdrawal is associated with depressed erythropoiesis in HD, a disease characterized by diminished endogenous EPO production [147]. The consequently decreasing proportion of young RBCs, containing low levels of GSSG and high levels of GSH [143], may also contribute to the elevation of the whole blood GSSG/GSH levels.

Finally, EPO has been reported to activate cJun- $N$-terminal kinases (JNKs) in erythroid cells [122]. JNKs may, in turn, stimulate heme oxygenase-1 [148] and Forkhead box class O (FOXO) transcription factor FOXO3a in response to oxidative stress [149]. FOXO3a activation is reported to be parallelled by elevated SOD, CAT and GPx expressions and an increased survival $[150,151]$. As mature RBCs do not have nuclei and cannot induce FOXO3a, they are dependent on antioxidant enzymes synthesized during early erythroid differentiation [151], even if post-translational modifications of the enzymes may have an influence on their activities [152153]. Therefore, a decrease of the JNK activity shortly after ESA withdrawal [122] could contribute to an attenuation of the FOXO3a-mediated stress tolerance in erythroid cells, and also an increased sensitivity of RBCs to free heme due to a lower activity of heme oxygenase-1.

Four weeks after ESA readministration, the level of oxidative stress was significantly elevated in both HD groups, with a subsequent return to the baseline level (Figure 6 and Table 4). Despite the distinct pharmacokinetic characteristics of epoetin beta and darbepoetin alfa $[154,155]$ and the marked changes in the oxidative parameters during the follow-up, no statistically significant difference between the groups, except for E-SOD, was found. Modest variances were present already at baseline and week 2 when identical interventions were performed in both groups. It was a noteworthy finding that the trend of the changes in the level of $\mathrm{Hb}$ was opposite to that shown by the oxidative parameters, in accordance with the suggested association between the degree of anemia and the level of oxidative stress $[65,69]$. Moreover, the time courses and magnitudes of the oxidative alterations in the present study with darbepoetin alfa and epoetin beta, and those in a previous study with epoetin alfa [60], 
were remarkably similar. These findings raise the possibility that the changes in oxidative stress during ESA therapy may be generated by factors associated with the correction of anemia, and not the direct effect of ESA. To confirm this hypothesis, assessments of the effects of different administration doses and frequencies of ESA, and studies comprising larger patient cohorts with a parallel-group or cross-over design, are suggested. 


\section{SUMMARY}

The microvascular responses to endothelium-dependent and -independent vasodilators ( $\mathrm{ACH}$ and SNP, respectively) and to local heating were studied in adolescents with primary hypertension grouped according to their BMI ( $\mathrm{LH}, \mathrm{OWH}$ and $\mathrm{OBH})$. It emerged that the endothelium-dependent vasorelaxation was not significantly attenuated in any of the hypertensive groups. This finding does not support the (otherwise clinically attractive) hypothesis of predicting the development of juvenile hypertension via noninvasive assessment of the endothelial function with LDF. In contrast, the endothelium-independent vasodilation was significantly impaired in the $\mathrm{LH}$ and $\mathrm{OBH}$ patients as compared with the controls. The microvascular reactivities were not related to differences in the levels of oxidative markers, even if the presence of an increased oxidative stress was confirmed in all the hypertensive groups. Prospective studies on larger populations of adolescents, which also assess the mechanisms of the microvascular responses to different stimuli, could clarify these issues.

An impairment of the endothelium-dependent and -independent vasodilations and the presence of a markedly increased oxidative stress were confirmed in HD patients. Among possible factors influencing the oxidative stress, substantial characteristics of ESA treatment (type and withdrawal of ESA) were studied. A significant elevation of the ratio GSSG/GSH was revealed directly after the interruption of epoetin beta treatment. Four weeks after darbepoetin alfa or epoetin beta therapy resumption, the levels of GSSG/GSH, GSSG and E-MDA were significantly increased in both groups as compared with the baseline. In line with the reported antioxidant effect of the sustained ESA administration, these parameters had returned to the baseline values by the end of the 12-week follow-up, parallelled with increased GSH and E-CAT activity levels. The findings of an opposite trend in the levels of $\mathrm{Hb}$ and oxidative markers, and similarities in the time courses and magnitudes of the oxidative alterations during the treatment with different ESAs suggest that the observed changes may primarily be caused by factors associated with the correction of anemia, rather than the direct effect of ESA. This emerging hypothesis is yet to be confirmed. 


\section{ORIGINAL FINDINGS}

1. The endothelium-dependent microvascular reactivity is not significantly attenuated in primary hypertensive adolescents being lean, overweight or obese.

2. The endothelium-independent vasodilation is significantly impaired in the $\mathrm{LH}$ and $\mathrm{OBH}$ groups, but not in the OWH patients, as compared with the controls.

3. The microvascular reactivities are not related to differences in the levels of oxidative markers, even if the presence of an increased oxidative stress is confirmed in all the hypertensive groups.

4. An increased oxidative stress is revealed by significantly elevated ratios GSSG/GSH directly after the withdrawal of epoetin beta treatment in HD patients.

5. The levels of GSSG/GSH, GSSG and E-MDA are significantly increased and the activities of E-SOD are significantly decreased four weeks after darbepoetin alfa or epoetin beta therapy resumption as compared with the baseline.

6. The levels of GSSG/GSH, GSSG and E-MDA return to the baseline values by the end of the 12-week follow-up after darbepoetin alfa or epoetin beta therapy resumption, parallelled with increased GSH and E-CAT activity levels. 


\section{ACKNOWLEDGMENTS ARE DUE TO}

my wife, Dr. Ildikó Farkas, for always being there. I thank her for her love, friendship, sincerity, inspiration, patience and continuous support within scientific life and beyond,

my parents and relatives, for their holding out and for the comforting atmosphere provided, my friends and colleagues, for their friendship and scientific talks (Dr. Ákos Baráth, Dr. Zoltán Maróti, Dr. Ágnes Maróti-Nagy, Dr. Zsuzsanna Ökrös, Dr. Ida Jusztina Kovács, Dr. Zsolt Makai, Dr. István Sás, Attila Ács, Tamás Troján, József Takács, Róbert Rádai, Anita Schulpe, Györgyi Kovács, Adrienn Boros, Dr. Ágnes Csanádi, Dr. Izabella Gombos, Dr. Balázs Kormányos and Piroska Dékány),

Ilona Szécsi and Ágota Fábiánné Nagy, for their excellent laboratory work,

Dr. Eszter Hódi and Dr. Adrienn Máté, for their contributions in the microvascular reactivity measurements and for the useful talks,

Dr. Ilona Szöllősiné Varga and Dr. Zsuzsanna Hracskó, for their cooperation in the antioxidant enzyme measurements and their advice,

Dr. Katalin Farkas (St. Imre Hospital, Budapest, Hungary) and Peter Jady (Moor Instruments Ltd., Axminster, UK) for providing me deep insight into the laser Doppler technique,

Dr. Eszter Karg and Dr. Gyula Wittmann, for their scientific encouragement, knowledge and exemplary attitude,

Prof. Dr. Ilona Németh, for being my first supervisor and for her encouragement,

Prof. Dr. Sándor Túri, for accepting me as a Ph.D. student in the Department of Pediatrics, for the constant scientific consultation and for ensuring all the conditions needed for the experiments,

and to all participating patients, controls and their parents, without whom these advances could not have been achieved.

This work was supported by Hungarian National Scientific Research Grant OTKA K67895 and by a Research\&Development Grant of the Hungarian Society of Nephrology. 


\section{REFERENCES}

1. Valko M, Leibfritz D, Moncol J, Cronin MT, Mazur M, Telser J. Free radicals and antioxidants in normal physiological functions and human disease. Int $\mathbf{J}$ Biochem Cell Biol. 2007; 39: 44-84.

2. Dröge W. Free radicals in the physiological control of cell function. Physiol Rev. 2002; 82: 47-95.

3. Halliwell B. Reactive species and antioxidants. Redox biology is a fundamental theme of aerobic life. Plant Physiol. 2006; 141: 312-322.

4. Dalle-Donne I, Rossi R, Colombo R, Giustarini D, Milzani A. Biomarkers of oxidative damage in human disease. Clin Chem. 2006; 52: 601-623.

5. Kopple JD. Phenylalanine and tyrosine metabolism in chronic kidney failure. J Nutr. 2007; 137 (6 Suppl 1): 1586S-1590S.

6. Molnár GA, Wagner Z, Markó L, Kó Szegi T, Mohás M, Kocsis B, Matus Z, Wagner L, Tamaskó M, Mazák I, Laczy B, Nagy J, Wittmann I. Urinary ortho-tyrosine excretion in diabetes mellitus and renal failure: evidence for hydroxyl radical production. Kidney Int. 2005; 68: 2281-2287.

7. Locatelli F, Canaud B, Eckardt KU, Stenvinkel P, Wanner C, Zoccali C. Oxidative stress in end-stage renal disease: an emerging threat to patient outcome. Nephrol Dial Transplant. 2003; 18: 1272-1280.

8. National High Blood Pressure Education Program Working Group on High Blood Pressure in Children and Adolescents. The fourth report on the diagnosis, evaluation, and treatment of high blood pressure in children and adolescents. Pediatrics. 2004; 114 (Suppl 4th Report): 555-576.

9. Lurbe E, Cifkova R, Cruickshank JK, Dillon MJ, Ferreira I, Invitti C, Kuznetsova T, Laurent S, Mancia G, Morales-Olivas F, Rascher W, Redon J, Schaefer F, Seeman T, Stergiou G, Wühl E, Zanchetti A; European Society of Hypertension. Management of high blood pressure in children and adolescents: recommendations of the European Society of Hypertension. J Hypertens. 2009; 27: 1719-1742. 
10. McCrindle BW. Assessment and management of hypertension in children and adolescents. Nat Rev Cardiol. 2010; 7: 155-163.

11. Meyers K, Falkner B. Hypertension in children and adolescents: an approach to management of complex hypertension in pediatric patients. Curr Hypertens Rep. 2009; 11: 315-322.

12. Staessen JA, Wang J, Bianchi G, Birkenhäger WH. Essential hypertension. Lancet. 2003; 361: 1629-1641.

13. Oparil S, Zaman MA, Calhoun DA. Pathogenesis of hypertension. Ann Intern Med. 2003; 139: 761-776.

14. Mancia G, De Backer G, Dominiczak A, Cifkova R, Fagard R, Germano G, Grassi G, Heagerty AM, Kjeldsen SE, Laurent S, Narkiewicz K, Ruilope L, Rynkiewicz A, Schmieder RE, Boudier HA, Zanchetti A, Vahanian A, Camm J, De Caterina R, Dean V, Dickstein K, Filippatos G, Funck-Brentano C, Hellemans I, Kristensen SD, McGregor K, Sechtem U, Silber S, Tendera M, Widimsky P, Zamorano JL, Erdine S, Kiowski W, Agabiti-Rosei E, Ambrosioni E, Lindholm LH, Viigimaa M, Adamopoulos S, AgabitiRosei E, Ambrosioni E, Bertomeu V, Clement D, Erdine S, Farsang C, Gaita D, Lip G, Mallion JM, Manolis AJ, Nilsson PM, O’Brien E, Ponikowski P, Redon J, Ruschitzka F, Tamargo J, van Zwieten P, Waeber B, Williams B; Management of Arterial Hypertension of the European Society of Hypertension; European Society of Cardiology. 2007 Guidelines for the Management of Arterial Hypertension: The Task Force for the Management of Arterial Hypertension of the European Society of Hypertension (ESH) and of the European Society of Cardiology (ESC). J Hypertens. 2007; 25: 1105-1187.

15. Falkner B. Hypertension in children and adolescents: epidemiology and natural history. Pediatr Nephrol. 2010; 25: 1219-1224.

16. Lassegue B, Griendling KK. Reactive oxygen species in hypertension. Am J Hypertens. 2004; 17: 852-860.

17. Lobstein T, Baur L, Uauy R; IASO International Obesity TaskForce. Obesity in children and young people: a crisis in public health. Obes Rev. 2004; 5 (Suppl 1): 4-104.

18. Lissau I, Overpeck MD, Ruan WJ, Due P, Holstein BE, Hediger ML; Health Behaviour in School-aged Children Obesity Working Group. Body mass index and overweight in 
adolescents in 13 European countries, Israel, and the United States. Arch Pediatr Adolesc Med. 2004; 158: 27-33.

19. Lobstein T, Frelut ML. Prevalence of overweight among children in Europe. Obes Rev. 2003; 4: 195-200.

20. Speiser PW, Rudolf MC, Anhalt H, Camacho-Hubner C, Chiarelli F, Eliakim A, Freemark M, Gruters A, Hershkovitz E, Iughetti L, Krude H, Latzer Y, Lustig RH, Pescovitz OH, Pinhas-Hamiel O, Rogol AD, Shalitin S, Sultan C, Stein D, Vardi P, Werther GA, Zadik Z, Zuckerman-Levin N, Hochberg Z; Obesity Consensus Working Group. Childhood obesity. J Clin Endocrinol Metab. 2005; 90: 1871-1887.

21. Ogden CL, Kuczmarski RJ, Flegal KM, Mei Z, Guo S, Wei R, Grummer-Strawn LM, Curtin LR, Roche AF, Johnson CL. Centers for Disease Control and Prevention 2000 growth charts for the United States: improvements to the 1977 National Center for Health Statistics version. Pediatrics. 2002; 109: 45-60.

22. Cole TJ, Bellizzi MC, Flegal KM, Dietz WH. Establishing a standard definition for child overweight and obesity worldwide: international survey. BMJ. 2000; 320: 12401243.

23. Kapiotis S, Holzer G, Schaller G, Haumer M, Widhalm H, Weghuber D, Jilma B, Röggla G, Wolzt M, Widhalm K, Wagner OF. A proinflammatory state is detectable in obese children and is accompanied by functional and morphological vascular changes. Arterioscler Thromb Vasc Biol. 2006; 26: 2541-2546.

24. Desideri G, De Simone M, Iughetti L, Rosato T, Iezzi ML, Marinucci MC, Cofini V, Croce G, Passacquale G, Necozione S, Ferri C. Early activation of vascular endothelial cells and platelets in obese children. J Clin Endocrinol Metab. 2005; 90: 3145-3152.

25. Ghergherechi R, Tabrizi A. Prevalence of impaired glucose tolerance and insulin resistance among obese children and adolescents. Ther Clin Risk Manag. 2010; 6: 345349.

26. Kempf K, Rathmann W, Herder C. Impaired glucose regulation and type 2 diabetes in children and adolescents. Diabetes Metab Res Rev. 2008; 24: 427-437.

27. McCrindle BW. Hyperlipidemia in children. Thromb Res. 2006; 118: 49-58. 
28. Reinehr T, de Sousa G, Toschke AM, Andler W. Long-term follow-up of cardiovascular disease risk factors in children after an obesity intervention. Am J Clin Nutr. 2006; 84: 490-496.

29. Pierce GL, Beske SD, Lawson BR, Southall KL, Benay FJ, Donato AJ, Seals DR. Weight loss alone improves conduit and resistance artery endothelial function in young and older overweight/obese adults. Hypertension. 2008; 52: 72-79.

30. Meyer AA, Kundt G, Lenschow U, Schuff-Werner P, Kienast W. Improvement of early vascular changes and cardiovascular risk factors in obese children after a six-month exercise program. J Am Coll Cardiol. 2006; 48: 1865-1870.

31. Wunsch R, de Sousa G, Toschke AM, Reinehr T. Intima-media thickness in obese children before and after weight loss. Pediatrics. 2006; 118: 2334-2340.

32. Vincent HK, Innes KE, Vincent KR. Oxidative stress and potential interventions to reduce oxidative stress in overweight and obesity. Diabetes Obes Metab. 2007; 9: 813839.

33. Galili O, Versari D, Sattler KJ, Olson ML, Mannheim D, McConnell JP, Chade AR, Lerman LO, Lerman A. Early experimental obesity is associated with coronary endothelial dysfunction and oxidative stress. Am J Physiol Heart Circ Physiol. 2007; 292: H904-911.

34. Atabek ME, Vatansev H, Erkul I. Oxidative stress in childhood obesity. J Pediatr Endocrinol Metab. 2004; 17: 1063-1068.

35. Yesilbursa D, Serdar Z, Serdar A, Sarac M, Coskun S, Jale C. Lipid peroxides in obese patients and effects of weight loss with orlistat on lipid peroxides levels. Int $\mathrm{J}$ Obes (Lond). 2005; 29: 142-145.

36. Decsi T, Molnár D, Koletzko B. Reduced plasma concentrations of alpha-tocopherol and beta-carotene in obese boys. J Pediatr. 1997; 130: 653-655.

37. Olusi SO. Obesity is an independent risk factor for plasma lipid peroxidation and depletion of erythrocyte cytoprotectic enzymes in humans. Int J Obes Relat Metab Disord. 2002; 26: 1159-1164.

38. Rahmouni K, Correia ML, Haynes WG, Mark AL. Obesity-associated hypertension: new insights into mechanisms. Hypertension. 2005; 45: 9-14. 
39. Gilardini L, Parati G, Sartorio A, Mazzilli G, Pontiggia B, Invitti C. Sympathoadrenergic and metabolic factors are involved in ambulatory blood pressure rise in childhood obesity. J Hum Hypertens. 2008; 22: 75-82.

40. Rahmouni K, Haynes WG. Leptin and the cardiovascular system. Recent Prog Horm Res. 2004; 59: 225-244.

41. Jun T, Ke-yan F, Catalano M. Increased superoxide anion production in humans: a possible mechanism for the pathogenesis of hypertension. J Hum Hypertens. 1996; 10: 305-309.

42. Kumar CA, Das UN. Lipid peroxides, anti-oxidants and nitric oxide in patients with pre-eclampsia and essential hypertension. Med Sci Monit. 2000; 6: 901-907.

43. Túri S, Friedman A, Bereczki C, Papp F, Kovàcs J, Karg E, Németh I. Oxidative stress in juvenile essential hypertension. J Hypertens. 2003; 21: 145-152.

44. Baráth A, Németh I, Karg E, Endreffy E, Bereczki C, Gellén B, Haszon I, Túri S. Roles of paraoxonase and oxidative stress in adolescents with uraemic, essential or obesityinduced hypertension. Kidney Blood Press Res. 2006; 29: 144-151.

45. Baráth A, Túri S, Németh I, Bereczki C, Gellén B, Haszon I, Monostori P. Different pathomechanisms of essential and obesity-associated hypertension in adolescents. Pediatr Nephrol. 2006; 21: 1419-1425.

46. Atkins RC. The epidemiology of chronic kidney disease. Kidney Int Suppl. 2005; 67 (Suppl 94): S14-18

47. Siems W, Quast S, Carluccio F, Wiswedel I, Hirsch D, Augustin W, Hampi H, Riehle M, Sommerburg O. Oxidative stress in chronic renal failure as a cardiovascular risk factor. Clin Nephrol. 2002; 58 (Suppl 1): S12-19.

48. Ceballos-Picot I, Witko-Sarsat V, Merad-Boudia M, Nguyen AT, Thévenin M, Jaudon MC, Zingraff J, Verger C, Jungers P, Descamps-Latscha B. Glutathione antioxidant system as a marker of oxidative stress in chronic renal failure. Free Radic Biol Med. 1996; 21: 845-853.

49. Locatelli F, Buoncristiani U, Canaud B, Köhler H, Petitclerc T, Zucchelli P. Dialysis dose and frequency. Nephrol Dial Transplant. 2005; 20: 285-296.

50. Handelman GJ. Evaluation of oxidant stress in dialysis patients. Blood Purif. 2000; 18: 343-349. 
51. Ward RA, McLeish KR. Oxidant stress in hemodialysis patients: what are the determining factors? Artif Organs. 2003; 27: 230-236.

52. Zwolinska D, Grzeszczak W, Szczepanska M, Kilis-Pstrusinska K, Szprynger K. Lipid peroxidation and antioxidant enzymes in children on maintenance dialysis. Pediatr Nephrol. 2006; 21: 705-710.

53. Fischbach M, Edefonti A, Schröder C, Watson A; European Pediatric Dialysis Working Group. Hemodialysis in children: general practical guidelines. Pediatr Nephrol. 2005; 20: 1054-1066.

54. Macías Núñez JF, Ghais Z, Bustamante J, Lopez-Novoa JM, Arrieta J, Barril G, Del Pino MD, Escaja C, Martín IM, Fernández Andrade C, García F, Núñez J, Onaindía JM, González J, Pérez-Prieto M, Fernández M, Lopez J, Santiago JM, Vicens M, Sousa F. Evaluation of oxidant-antioxidant balance in patients on maintenance haemodialysis: a comparative study of dialyzers membranes. Nephron Clin Pract. 2010; 114: c67-73.

55. Kosch M, Levers A, Fobker M, Barenbrock M, Schaefer RM, Rahn KH, Hausberg M. Dialysis filter type determines the acute effect of haemodialysis on endothelial function and oxidative stress. Nephrol Dial Transplant. 2003; 18: 1370-1375.

56. Müller C, Eisenbrand G, Gradinger M, Rath T, Albert FW, Vienken J, Singh R, Farmer PB, Stockis JP, Janzowski C. Effects of hemodialysis, dialyser type and iron infusion on oxidative stress in uremic patients. Free Radic Res. 2004; 38: 1093-1100.

57. Stepniewska J, Dolegowska B, Ciechanowski K, Kwiatkowska E, Millo B, Chlubek D. Erythrocyte antioxidant defense system in patients with chronic renal failure according to the hemodialysis conditions. Arch Med Res. 2006; 37: 353-359.

58. Locatelli F, Pisoni RL, Combe C, Bommer J, Andreucci VE, Piera L, Greenwood R, Feldman HI, Port FK, Held PJ. Anaemia in haemodialysis patients of five European countries: association with morbidity and mortality in the Dialysis Outcomes and Practice Patterns Study (DOPPS). Nephrol Dial Transplant. 2004; 19: 121-132.

59. Locatelli F, Aljama P, Bárány P, Canaud B, Carrera F, Eckardt KU, Hörl WH, Macdougal IC, Macleod A, Wiecek A, Cameron S; European Best Practice Guidelines Working Group. Revised European best practice guidelines for the management of anaemia in patients with chronic renal failure. Nephrol Dial Transplant. 2004; 19 (Suppl 2): ii1-47. 
60. Turi S, Nemeth I, Varga I, Bodrogi T, Matkovics B. The effect of erythropoietin on the cellular defence mechanism of red blood cells in children with chronic renal failure. Pediatr Nephrol. 1992; 6: 536-541.

61. Németh I, Túri S, Haszon I, Bereczki C. Vitamin E alleviates the oxidative stress of erythropoietin in uremic children on hemodialysis. Pediatr Nephrol. 2000; 14: 13-17.

62. Mimic-Oka J, Simic T, Djukanovic L. Epoetin treatment improves red blood cell and plasma antioxidant capacity in hemodialysis patients. Ren Fail. 2002; 24: 77-87.

63. Pawlak K, Pawlak D, Mysliwiec M. Erythropoietin therapy decreased tissue factor, its pathway inhibitor, and oxidative stress in peritoneal dialysis patients with diabetes. Nephron Clin Pract. 2007; 107: c20-25.

64. Inal M, Kanbak G, Sen S, Akyüz F, Sunal E. Antioxidant status and lipid peroxidation in hemodialysis patients undergoing erythropoietin and erythropoietin-vitamin $\mathrm{E}$ combined therapy. Free Radic Res. 1999; 31: 211-216.

65. Siems W, Carluccio F, Radenkovic S, Grune T, Hampl H. Oxidative stress in renal anemia of hemodialysis patients is mitigated by epoetin treatment. Kidney Blood Press Res. 2005; 28: 295-301.

66. Calò LA, Stanic L, Davis PA, Pagnin E, Munaretto G, Fusaro M, Landini S, Semplicini A, Piccoli A. Effect of epoetin on HO-1 mRNA level and plasma antioxidants in hemodialysis patients. Int J Clin Pharmacol Ther. 2003; 41: 187-192.

67. Katavetin P, Tungsanga K, Eiam-Ong S, Nangaku M. Antioxidative effects of erythropoietin. Kidney Int Suppl. 2007; 107: S10-15.

68. Akisu M, Tuzun S, Arslanoglu S, Yalaz M, Kultursay N. Effect of recombinant human erythropoietin administration on lipid peroxidation and antioxidant enzyme(s) activities in preterm infants. Acta Med Okayama. 2001; 55: 357-362.

69. Lahera V, Goicoechea M, de Vinuesa SG, Oubiña P, Cachofeiro V, Gómez-Campderá F, Amann R, Luño J. Oxidative stress in uremia: the role of anemia correction. J Am Soc Nephrol. 2006; 17: S174-177.

70. Laurent S, Cockcroft J, Van Bortel L, Boutouyrie P, Giannattasio C, Hayoz D, Pannier B, Vlachopoulos C, Wilkinson I, Struijker-Boudier H; European Network for Noninvasive Investigation of Large Arteries. Expert consensus document on arterial stiffness: methodological issues and clinical applications. Eur Heart J. 2006; 27: 2588-2605. 
71. Baulmann J, Schillings U, Rickert S, Uen S, Düsing R, Illyes M, Cziraki A, Nickering G, Mengden T. A new oscillometric method for assessment of arterial stiffness: comparison with tonometric and piezo-electronic methods. J Hypertens. 2008; 26: 523528.

72. Rajzer MW, Wojciechowska W, Klocek M, Palka I, Brzozowska-Kiszka M, KaweckaJaszcz K. Comparison of aortic pulse wave velocity measured by three techniques: Complior, SphygmoCor and Arteriograph. J Hypertens. 2008; 26: 2001-2007.

73. Jatoi NA, Mahmud A, Bennett K, Feely J. Assessment of arterial stiffness in hypertension: comparison of oscillometric (Arteriograph), piezoelectronic (Complior) and tonometric (SphygmoCor) techniques. J Hypertens. 2009; 27: 2186-2191.

74. Zebekakis PE, Nawrot T, Thijs L, Balkestein EJ, van der Heijden-Spek J, Van Bortel LM, Struijker-Boudier HA, Safar ME, Staessen JA. Obesity is associated with increased arterial stiffness from adolescence until old age. J Hypertens. 2005; 23: 1839-1846.

75. Laurent S, Boutouyrie P, Asmar R, Gautier I, Laloux B, Guize L, Ducimetiere P, Benetos A. Aortic stiffness is an independent predictor of all-cause and cardiovascular mortality in hypertensive patients. Hypertension. 2001; 37: 1236-1241.

76. Othmane Tel H, Nemcsik J, Fekete BC, Deák G, Egresits J, Fodor E, Logan AG, Németh ZK, Járai Z, Szabó T, Szathmári M, Kiss I, Tislér A. Arterial stiffness in hemodialysis: which parameter to measure to predict cardiovascular mortality? Kidney Blood Press Res. 2009; 32: 250-257.

77. Plantinga Y, Ghiadoni L, Magagna A, Giannarelli C, Penno G, Pucci L, Taddei S, Del Prato S, Salvetti A. Peripheral wave reflection and endothelial function in untreated essential hypertensive patients with and without the metabolic syndrome. J Hypertens. 2008; 26: 1216-1222.

78. Gil TY, Sung CY, Shim SS, Hong YM. Intima-media thickness and pulse wave velocity in hypertensive adolescents. J Korean Med Sci. 2008; 23: 35-40.

79. Alam TA, Seifalian AM, Baker D. A review of methods currently used for assessment of in vivo endothelial function. Eur J Vasc Endovasc Surg. 2005; 29: 269-276.

80. Yvonne-Tee GB, Rasool AH, Halim AS, Rahman AR. Noninvasive assessment of cutaneous vascular function in vivo using capillaroscopy, plethysmography and laser- 
Doppler instruments: its strengths and weaknesses. Clin Hemorheol Microcirc. 2006; 34: 457-473.

81. Ghiadoni L, Taddei S, Virdis A, Sudano I, Di Legge V, Meola M, Di Venanzio L, Salvetti A. Endothelial function and common carotid artery wall thickening in patients with essential hypertension. Hypertension. 1998; 32: 25-32.

82. Annuk M, Zilmer M, Lind L, Linde T, Fellstrom B. Oxidative stress and endothelial function in chronic renal failure. J Am Soc Nephrol. 2001; 12: 2747-2752.

83. Deanfield J, Donald A, Ferri C, Giannattasio C, Halcox J, Halligan S, Lerman A, Mancia G, Oliver JJ, Pessina AC, Rizzoni D, Rossi GP, Salvetti A, Schiffrin EL, Taddei S, Webb DJ; Working Group on Endothelin and Endothelial Factors of the European Society of Hypertension. Endothelial function and dysfunction. Part I: Methodological issues for assessment in the different vascular beds: a statement by the Working Group on Endothelin and Endothelial Factors of the European Society of Hypertension. J Hypertens. 2005; 23: 7-17.

84. Meyer AA, Kundt G, Steiner M, Schuff-Werner P, Kienast W. Impaired flow-mediated vasodilation, carotid artery intima-media thickening, and elevated endothelial plasma markers in obese children: the impact of cardiovascular risk factors. Pediatrics. 2006; 117: $1560-1567$.

85. Ghiadoni L, Cupisti A, Huang Y, Mattei P, Cardinal H, Favilla S, Rindi P, Barsotti G, Taddei S, Salvetti A. Endothelial dysfunction and oxidative stress in chronic renal failure. J Nephrol. 2004; 17: 512-519.

86. Głowińska-Olszewska B, Tołwińska J, Urban M. Relationship between endothelial dysfunction, carotid artery intima media thickness and circulating markers of vascular inflammation in obese hypertensive children and adolescents. J Pediatr Endocrinol Metab. 2007; 20: 1125-1136.

87. Iiyama K, Nagano M, Yo Y, Nagano N, Kamide K, Higaki J, Mikami H, Ogihara T. Impaired endothelial function with essential hypertension assessed by ultrasonography. Am Heart J. 1996; 132: 779-782.

88. Muiesan ML, Salvetti M, Paini A, Monteduro C, Galbassini G, Poisa P, Porteri E, Agabiti-Rosei C, Paderno V, Belotti E, Rizzoni D, Castellano M, Agabiti-Rosei E. 
Prognostic role of flow-mediated dilatation of the brachial artery in hypertensive patients. J Hypertens. 2008; 26: 1612-1618.

89. Jonk AM, Houben AJ, de Jongh RT, Serné EH, Schaper NC, Stehouwer CD. Microvascular dysfunction in obesity: a potential mechanism in the pathogenesis of obesity-associated insulin resistance and hypertension. Physiology (Bethesda). 2007; 22: 252-260.

90. Leahy MJ, de Mul FF, Nilsson GE, Maniewski R. Principles and practice of the laserDoppler perfusion technique. Technol Health Care. 1999; 7: 143-162.

91. Turner J, Belch JJ, Khan F. Current concepts in assessment of microvascular endothelial function using laser Doppler imaging and iontophoresis. Trends Cardiovasc Med. 2008; 18: 109-116.

92. Hansell J, Henareh L, Agewall S, Norman M. Non-invasive assessment of endothelial function - relation between vasodilatory responses in skin microcirculation and brachial artery. Clin Physiol Funct Imaging. 2004; 24: 317-322.

93. Debbabi H, Bonnin P, Ducluzeau PH, Lefthériotis G, Levy BI. Noninvasive assessment of endothelial function in the skin microcirculation. Am J Hypertens. 2010; 23: 541-546.

94. Khan F, Patterson D, Belch JJ, Hirata K, Lang CC. Relationship between peripheral and coronary function using laser Doppler imaging and transthoracic echocardiography. Clin Sci (Lond). 2008; 115: 295-300.

95. Engelberger RP, Teta D, Henry H, De Senarclens O, Dischl B, Liaudet L, Burnier M, Waeber B, Feihl F. Haemodialysis acutely reduces the plasma levels of ADMA without reversing impaired NO-dependent vasodilation. Clin Sci (Lond). 2009; 117: 293-303.

96. Farkas K, Nemcsik J, Kolossváry E, Járai Z, Nádory E, Farsang C, Kiss I. Impairment of skin microvascular reactivity in hypertension and uraemia. Nephrol Dial Transplant. 2005; 20: 1821-1827.

97. Cupisti A, Rossi M, Placidi S, Caprioli R, Morelli E, Vagheggini G, Barsotti G. Responses of the skin microcirculation to acetylcholine and to sodium nitroprusside in chronic uremic patients. Int J Clin Lab Res. 2000; 30: 157-162.

98. Farkas K, Kolossváry E, Járai Z, Nemcsik J, Farsang C. Non-invasive assessment of microvascular endothelial function by laser Doppler flowmetry in patients with essential hypertension. Atherosclerosis. 2004; 173: 97-102. 
99. Lindstedt IH, Edvinsson ML, Edvinsson L. Reduced responsiveness of cutaneous microcirculation in essential hypertension--a pilot study. Blood Press. 2006; 15: 275-280.

100. Khan F, Elhadd TA, Greene SA, Belch JJ. Impaired skin microvascular function in children, adolescents, and young adults with type 1 diabetes. Diabetes Care. 2000; 23: 215-220.

101. Minson CT, Berry LT, Joyner MJ. Nitric oxide and neurally mediated regulation of skin blood flow during local heating. J Appl Physiol. 2001; 91: 1619-1626.

102. Cracowski JL, Minson CT, Salvat-Melis M, Halliwill JR. Methodological issues in the assessment of skin microvascular endothelial function in humans. Trends Pharmacol Sci. 2006; 27: 503-508.

103. Droog EJ, Henricson J, Nilsson GE, Sjöberg F. A protocol for iontophoresis of acetylcholine and sodium nitroprusside that minimises nonspecific vasodilatory effects. Microvasc Res. 2004; 67: 197-202.

104. Ferrell WR, Ramsay JE, Brooks N, Lockhart JC, Dickson S, McNeece GM, Greer IA, Sattar N. Elimination of electrically induced iontophoretic artefacts: implications for noninvasive assessment of peripheral microvascular function. J Vasc Res. 2002; 39: 447-455.

105. Lim PS, Wei YH, Yu YL, Kho B. Enhanced oxidative stress in haemodialysis patients receiving intravenous iron therapy. Nephrol Dial Transplant. 1999; 14: 2680-2687.

106. Nemeth I, Boda D. Blood glutathione redox ratio as a parameter of oxidative stress in premature infants with IRDS. Free Radic Biol Med. 1994; 16: 347-353.

107. Hess D, Keller HE, Oberlin B, Bonfanti R, Schüep W. Simultaneous determination of retinol, tocopherols, carotenes and lycopene in plasma by means of high-performance liquid chromatography on reversed phase. Int J Vitam Nutr Res. 1991; 61: 232-238.

108. Peuchant E, Carbonneau MA, Dubourg L, Thomas MJ, Perromat A, Vallot C, Clerc M. Lipoperoxidation in plasma and red blood cells of patients undergoing haemodialysis: vitamins A, E, and iron status. Free Radic Biol Med. 1994; 16: 339-346.

109. Misra HP, Fridovich I. The role of superoxide anion in the autoxidation of epinephrine and a simple assay for superoxide dismutase. J Biol Chem. 1972; 247: 3170-3175.

110. Matkovics B, László A, Szabó L. A comparative study of superoxide dismutase, catalase and lipid peroxidation in red blood cells from muscular dystrophy patients and normal controls. Clin Chim Acta. 1982; 118: 289-292. 
111. Beers RF Jr, Sizer IW. A spectrophotometric method for measuring the breakdown of hydrogen peroxide by catalase. J Biol Chem. 1952; 195: 133-140.

112. Lowry OH, Rosebrough NJ, Farr AL, Randall RJ. Protein measurement with the Folin phenol reagent. J Biol Chem. 1951; 193: 265-275.

113. Wühl E, Witte K, Soergel M, Mehls O, Schaefer F; German Working Group on Pediatric Hypertension. Distribution of 24-h ambulatory blood pressure in children: normalized reference values and role of body dimensions. J Hypertens. 2002; 20: 19952007.

114. Tattersall J, Martin-Malo A, Pedrini L, Basci A, Canaud B, Fouque D, Haage P, Konner K, Kooman J, Pizzarelli F, Tordoir J, Vennegoor M, Wanner C, ter Wee P, Vanholder R. EBPG guideline on dialysis strategies. Nephrol Dial Transplant. 2007; 22: ii5-21.

115. Widlansky ME, Gokce N, Keaney JF Jr, Vita JA. The clinical implications of endothelial dysfunction. J Am Coll Cardiol. 2003; 42: 1149-1160.

116. Ostchega Y, Carroll M, Prineas RJ, McDowell MA, Louis T, Tilert T. Trends of elevated blood pressure among children and adolescents: data from the National Health and Nutrition Examination Survey1988-2006. Am J Hypertens. 2009; 22: 59-67.

117. Chen X, Wang Y. Tracking of blood pressure from childhood to adulthood: a systematic review and meta-regression analysis. Circulation. 2008; 117: 3171-3180.

118. Field AE, Cook NR, Gillman MW. Weight status in childhood as a predictor of becoming overweight or hypertensive in early adulthood. Obes Res. 2005; 13: 163-169.

119. Kellogg DL Jr. In vivo mechanisms of cutaneous vasodilation and vasoconstriction in humans during thermoregulatory challenges. J Appl Physiol. 2006; 100: 1709-1718.

120. Tesselaar E, Henricson J, Jonsson S, Sjöberg F. A time-response model for analysis of drug transport and blood flow response during iontophoresis of acetylcholine and sodium nitroprusside. J Vasc Res. 2009; 46: 270-277.

121. Alfrey CP, Fishbane S. Implications of neocytolysis for optimal management of anaemia in chronic kidney disease. Nephron Clin Pract. 2007; 106: c149-156.

122. Jacobs-Helber SM, Ryan JJ, Sawyer ST. JNK and p38 are activated by erythropoietin (EPO) but are not induced in apoptosis following EPO withdrawal in EPO-dependent HCD57 cells. Blood. 2000; 96: 933-940. 
123. Borawski J, Myśliwiec M. Effects of recombinant erythropoietin therapy on circulating endothelial markers in hemodialysis patients. Clin Appl Thromb Hemost. 2002; 8: 77-84.

124. Dickinson DA, Moellering DR, Iles KE, Patel RP, Levonen AL, Wigley A, DarleyUsmar VM, Forman HJ. Cytoprotection against oxidative stress and the regulation of glutathione synthesis. Biol Chem. 2003; 384: 527-537.

125. Khalil A, Sareen R, Mallika V, Chowdhury V. Non-invasive evaluation of endothelial function, arterial mechanics and nitric oxide levels in children of hypertensive parents. Indian Heart J. 2008; 60: 34-38.

126. Zizek B, Poredos P. Insulin resistance adds to endothelial dysfunction in hypertensive patients and in normotensive offspring of subjects with essential hypertension. J Intern Med. 2001; 249: 189-197.

127. Mohler ER 3rd, O'Hare K, Darze ES, Townsend RR, Bridges CR Jr, Keane MG. Cardiovascular function in normotensive offspring of persons with essential hypertension and black race. J Clin Hypertens (Greenwich). 2007; 9: 506-512.

128. Yang Z, Kaye DM. Endothelial dysfunction and impaired L-arginine transport in hypertension and genetically predisposed normotensive subjects. Trends Cardiovasc Med. 2006; 16: 118-124.

129. Paniagua OA, Bryant MB, Panza JA. Transient hypertension directly impairs endothelium-dependent vasodilation of the human microvasculature. Hypertension. 2000; 36: 941-944.

130. Juonala M, Viikari JS, Rönnemaa T, Helenius H, Taittonen L, Raitakari OT. Elevated blood pressure in adolescent boys predicts endothelial dysfunction: the cardiovascular risk in young Finns study. Hypertension. 2006; 48: 424-430.

131. Katona E, Settakis G, Varga Z, Paragh G, Bereczki D, Fülesdi B, Páll D. Target-organ damage in adolescent hypertension. Analysis of potential influencing factors, especially nitric oxide and endothelin-1. J Neurol Sci. 2006; 247: 138-143.

132. Morris SJ, Shore AC. Skin blood flow responses to the iontophoresis of acetylcholine and sodium nitroprusside in man: possible mechanisms. J Physiol. 1996; 496: 531-542.

133. Holowatz LA, Thompson CS, Minson CT, Kenney WL. Mechanisms of acetylcholinemediated vasodilatation in young and aged human skin. J Physiol. 2005; 563: 965-973. 
134. Lavie CJ, Milani RV, Ventura HO. Obesity and cardiovascular disease: risk factor, paradox, and impact of weight loss. J Am Coll Cardiol. 2009; 53: 1925-1320.

135. Barrett-Connor E, Khaw KT. Is hypertension more benign when associated with obesity? Circulation. 1985; 72: 53-60.

136. Carman WJ, Barrett-Connor E, Sowers M, Khaw KT. Higher risk of cardiovascular mortality among lean hypertensive individuals in Tecumseh, Michigan. Circulation. 1994; 89: 703-711.

137. Silventoinen K, Magnusson PK, Neovius M, Sundström J, Batty GD, Tynelius P, Rasmussen F. Does obesity modify the effect of blood pressure on the risk of cardiovascular disease? A population-based cohort study of more than one million Swedish men. Circulation. 2008; 118: 1637-1642.

138. Rao DN, Cederbaum AI. Production of nitric oxide and other iron-containing metabolites during the reductive metabolism of nitroprusside by microsomes and by thiols. Arch Biochem Biophys. 1995; 321: 363-371.

139. Ioannidis I, Bätz M, Paul T, Korth HG, Sustmann R, De Groot H. Enhanced release of nitric oxide causes increased cytotoxicity of S-nitroso-N-acetyl-DL-penicillamine and sodium nitroprusside under hypoxic conditions. Biochem J. 1996; 318: 789-795.

140. Ramsay JE, Ferrell WR, Greer IA, Sattar N. Factors critical to iontophoretic assessment of vascular reactivity: implications for clinical studies of endothelial dysfunction. $\mathbf{J}$ Cardiovasc Pharmacol. 2002; 39: 9-17.

141. De Blasi RA, Luciani R, Punzo G, Arcioni R, Romano R, Boezi M, Menè P. Microcirculatory changes and skeletal muscle oxygenation measured at rest by noninfrared spectroscopy in patients with and without diabetes undergoing haemodialysis. Crit Care. 2009;13 (Suppl 5):S9. (doi:10.1186/cc8007)

142. Rice L, Alfrey CP, Driscoll T, Whitley CE, Hachey DL, Suki W. Neocytolysis contributes to the anemia of renal disease. Am J Kidney Dis. 1999; 33: 59-62.

143. Clark MR. Senescence of red blood cells: progress and problems. Physiol Rev. 1988; 68: 503-554.

144. Kumar S, Bandyopadhyay U. Free heme toxicity and its detoxification systems in human. Toxicol Lett. 2005; 157: 175-188. 
145. Coxon A, Sinclair A, Archibeque I, Estrada J, Kaufman S, Rogers N, Swift S, Tran L, Elliott S. Endothelial cells express no detectable erythropoietin receptor protein and erythropoietin does not induce angiogenesis in vivo (abstract). Blood. 2007; 110: 4077.

146. Kiss Z, Elliott S, Jedynasty K, Tesar V, Szegedi J. Discovery and basic pharmacology of erythropoiesis-stimulating agents (ESAs), including the hyperglycosylated ESA, darbepoetin alfa: an update of the rationale and clinical impact. Eur J Clin Pharmacol. 2010; 66: 331-340.

147. Macdougall IC. Anaemia of chronic kidney disease. Medicine. 2007; 35: 457-460.

148. Calò LA, Davis PA, Piccoli A, Pessina AC. A role for heme oxygenase-1 in the antioxidant and antiapoptotic effects of erythropoietin: the start of a good news/bad news story? Nephron Physiol. 2006; 103: p107-111.

149. Essers MA, Weijzen S, de Vries-Smits AM, Saarloos I, de Ruiter ND, Bos JL, Burgering BM. FOXO transcription factor activation by oxidative stress mediated by the small GTPase Ral and JNK. EMBO J. 2004; 23: 4802-4812.

150. Kops GJ, Dansen TB, Polderman PE, Saarloos I, Wirtz KW, Coffer PJ, Huang TT, Bos JL, Medema RH, Burgering BM. Forkhead transcription factor FOXO3a protects quiescent cells from oxidative stress. Nature. 2002; 419: 316-321.

151. Marinkovic D, Zhang X, Yalcin S, Luciano JP, Brugnara C, Huber T, Ghaffari S. Foxo3 is required for the regulation of oxidative stress in erythropoiesis. J Clin Invest. 2007; 117: 2133-2144.

152. Yamakura F, Kawasaki H. Post-translational modifications of superoxide dismutase. Biochim Biophys Acta. 2010; 1804: 318-325.

153. Rhee SG, Yang KS, Kang SW, Woo HA, Chang TS. Controlled elimination of intracellular $\mathrm{H}(2) \mathrm{O}(2)$ : regulation of peroxiredoxin, catalase, and glutathione peroxidase via post-translational modification. Antioxid Redox Signal. 2005; 7: 619-626.

154. Deicher R, Hörl WH. Differentiating factors between erythropoiesis-stimulating agents: a guide to selection for anaemia of chronic kidney disease. Drugs. 2004; 64: 499-509.

155. Elliott S, Pham E, Macdougall IC. Erythropoietins: a common mechanism of action. Exp Hematol. 2008; 36: 1573-1584. 
9. APPENDIX 